\title{
Combinations of Plant Species for Rotation With Onion Crops: Effects on the Light Fraction, Carbon, and Nitrogen Contents in Granulometric Fractions of the Soil Organic Matter
}

\author{
Lucas Dupont Giumbelli, Arcângelo Loss \\ Universidade Federal de Santa Catarina, Florianopolis, Santa Catarina, Brazil. \\ E-mail: arcangelo.loss@ufsc.br
}

Claudinei Kurtz

Empresa de Pesquisa e Extensão Rural do Estado de Santa Catarina, Ituporanga, Santa Catrina, Brazil

Álvaro Luiz Mafra

Universidade do Estado de Santa Catarina, Lages, Santa Catarina, Brazil

Marisa de Cássia Piccolo

Universidade de São Paulo, Piracicaba, Sao Paulo, Brazil

José Luiz Rodrigues Torres

Instituto Federal do Triângulo Mineiro, Uberaba, Minas Gerais, Brazil

Cledimar Rogério Lourenzi

Universidade Federal de Santa Catarina, Florianopolis, Santa Catarina, Brazil

Gustavo Brunetto

Universidade Federal de Santa Maria, Santa Maria, Rio Grande do Sul, Brazil 
Jucinei José Comin

Universidade Federal de Santa Catarina, Florianopolis, Santa Catarina, Brazil

Received: Nov. 9, 2020

doi:10.5296/jas.v9i1.17930
Accepted: Nov. 24, $2020 \quad$ Published: Dec. 28, 2020

URL: https://doi.org/10.5296/jas.v9i1.17930

\begin{abstract}
The conversion of conventional tillage system (CTS) into no-tillage system (NTS) for onion crops with use of soil cover crops increases carbon and nitrogen contents in the soil aggregates. The objective of this work was to evaluate the effects of combinations of different plant species and soil management systems using rotation with soil cover crops for onion crops on the light organic matter (LOM), carbon (C), and nitrogen $(\mathrm{N})$ contents in the organic matter granulometric fractions in soil macroaggregates and bulk soil. A nine-year experiment (2007-2016) was conducted using the treatments (T): maize-onion in NTS (T1); soil cover crops (winter)-onion in NTS(T2); maize-winter grasses-onion in NTS (T3); velvet bean-onion in NTS (T4); millet-soil cover crops (winter)-onion in NTS (T5); velvet bean-rye-onion in NTS (T6); maize-onion in CTS (T7); intercropped soil cover crops (summer)-onion in NTS (T8). C and $\mathrm{N}$ contents in the LOM, particulate organic $\mathrm{C}$ and $\mathrm{N}$ (POC and PON), and mineral- associated $\mathrm{C}$ and $\mathrm{N}$ (MOC and MON) were evaluated in soil macroaggregates $(8.0$ to $2.0 \mathrm{~mm})$ and bulk soil $(<2.0 \mathrm{~mm})$ from the $0-5 \mathrm{~cm}, 5-10 \mathrm{~cm}$, and 10-20 cm layers. High diversity and combinations of plant species in T2-T6, and T8 resulted in higher POC and MON contents in aggregates, and higher MOC and PON contents in bulk soil, when compared to T1 and T7. T2 was a better option to increase LOM and POC contents in aggregates $(0-5 \mathrm{~cm})$. The evaluation of POC $(0-5 \mathrm{~cm}), \mathrm{PON}$, and MON $(0-10 \mathrm{~cm})$ contents in soil aggregates showed more significant differences between the treatments than the contents found in bulk soil. The onion crops under NTS combined with use of rotations with soil cover crops were more efficient to improve the evaluated soil attributes than those under CTS.
\end{abstract}

Keywords: particulate organic carbon, nitrogen particulate, cover crops, no-tillage system, soil aggregates, bulk soil

\title{
1. Introduction
}

Onion (Allium cepa) is a vegetable grown worldwide in approximately 9.2 million of hectares; China, India, and the USA are the main producers (FAO, 2020). Brazil is the tenth largest onion producer, with an estimated production of 1.61 million $\mathrm{Mg}$ in 2017, which decreased to 1.55 million $\mathrm{Mg}$ in 2018. For the 2019 harvest, an increase of $1.78 \%$ in the volume produced, and $1.94 \%$ in productivity, is expected. Santa Catarina (SC) is the largest onion producing state in Brazil, with approximately 470,000 and 529,210 Mg in 2018 and 2019, respectively; this production is concentrated in the Upper Itajaí River Valley, with emphasis in the municipality of Ituporanga, which leads the onion production (Menezes Junior et al., 2013; 
SEAP, 2017; IBGE, 2020).

Producers in SC traditionally use conventional tillage system (CTS) to prepare soils for onion crops, with frequent soil turning and use of highly-soluble soil fertilizers. Onion crops in CTS have degraded physical-chemical attributes of the soil, requiring alternatives to this system, such as no-tillage system (NTS) (Loss et al., 2015; Santos et al., 2018a,b; Loss et al., 2017a; Comin et al., 2018; Ferreira et al., 2018).

The NTS is based on minimum soil turning and presence of soil cover (alive or dead). The use of crop rotations, intercrops, green manure, and soil cover crops are practices constantly used in the NTS, which increase soil organic matter (SOM) contents. The SOM improves edaphic attributes, especially the nutrient availability, cation exchange capacity, soil microbial activity and biomass, and soil aggregation (Loss et al., 2015; Vezzani \& Mielniczuk, 2011; Tivet et al., 2013; Comin et al., 2018; Ferreira et al., 2018, Loss et al., 2019; Abdala et al., 2020).

Soil aggregates are indicators of soil quality, because they are susceptible to soil physical disturbances and can affect the SOM dynamics under different soil management systems (Fernández et al., 2010; Tivet et al., 2013: Loss et al., 2017b). The use of different soil cover crops, such as grass species, Brassicaceae species, and leguminous species, grown alone or intercropped in crop rotation systems can also affect the formation of soil aggregates and the dynamics of the SOM fractions in these aggregates (Comin et al., 2018; Ferreira et al., 2018). The soil cover crops also affect other factors, such as atmospheric carbon sequestration, due to the photosynthesis processes, and can form a favorable environment to microorganism growth because of the release of root exudates, which results in mineralization of nutrients contained in the SOM (Lange et al., 2015; Loss et al., 2019).

The granulometric fractions of carbon and nitrogen in the SOM can be divided into particulate organic carbon (POC) and particulate organic nitrogen (PON), which are related to soil particles with sizes $>53 \mu \mathrm{m}$; and into mineral-associated organic carbon (MOC) and mineral-associated organic nitrogen $(\mathrm{MON})$, which are related to soil particles with sizes $<53$ $\mu \mathrm{m}$ (Conceição et al., 2013; Lavallee et al., 2019).

POC and PON are originated from residues of shoots, non-completely decomposed plant roots, and fungus hyphae, and are protected mainly in the interior of soil aggregates. MOC and MON are originated from microbial tissues or metabolites of low molecular weight, and tend to form organo-mineral interactions with silt $(2-53 \mu \mathrm{m})$ and clay $(0-2 \mu \mathrm{m})$ particles; therefore, they are more recalcitrant in the soil and less sensitive to changes caused by soil managements (Lavallee et al., 2019; Chen et al., 2020).

Another SOM fraction that is directly related to deposition of plant residues on the soil is the light organic matter (LOM). This is a low-density organic matter fraction from plant residues on the soil surface and from roots little changed by microorganisms. The LOM size is between 2.0 and $0.25 \mathrm{~mm}$, and its total contribution to SOM varies from $45 \%$ to $60 \%$ (Anderson \& Ingran 1994). Loss et al. (2014) evaluated soil aggregation and quantified the LOM and total organic carbon (COT) contents in a soybean-rye rotation under NTS for 15 years, and in maize crops under CTS for 56 years, comparing them to areas with secondary 
forest, and extensive pasture (Axonopus compressus), both with more than 30 years; they found that the use of CTS results in lower aggregation indexes and LOM and COT contents when compared to the forest area, and the NTS.

In another study, the frequent soil turning in a maize-onion rotation under CTS decreased total $\mathrm{C}$ and $\mathrm{N}$ contents when compared to treatments using rotation with onion crops under NTS (Comin et al., 2018). This negative effect on soil quality is associated with decreases in stability of aggregates. Comin et al. (2018) also reported that soil management systems that do not use cover crops in rotation decreased $\mathrm{C}$ contents and presented less water-stable aggregates.

Some studies report that the evaluation of soil chemical attributes, such as $\mathrm{C}$ and $\mathrm{N}$ contents and SOM fractions, should not be restricted only to disturbed soil samples (Loss et al., 2015; Santos et al., 2017; Ferreira et al., 2018). These studies evaluated C contents and SOM fractions in soil aggregates (undisturbed samples). According to Loss et al. (2015) and Santos et al. (2017), there are significant differences in aggregation between soils managed under CTS and NTS, mainly for the macroaggregates class $(8.00 \mathrm{~mm}>\varnothing \geq 2.0 \mathrm{~mm})$. Ferreira et al. (2018) found that soil aggregates presented higher COT contents and particulate organic matter than bulk soil $(\varnothing<2.0 \mathrm{~mm})$; and the evaluation of SOM fractions in soil aggregates $(8.00 \mathrm{~mm}>\varnothing \geq 2.0 \mathrm{~mm})$ showed higher differences between the treatments (management systems and combinations of soil cover crops) than the evaluation of bulk soil $(\varnothing<2.0 \mathrm{~mm})$.

Therefore, the hypothesis proposed in the present study was that the conversion of onion crop areas under CTS into NTS with use of soil cover crops increases C and N contents in soil aggregates; and the differences between treatments using soil cover crops are more pronounced when evaluating the aggregates than the bulk soil. The objective of this work was to evaluate the effects of combinations of different plant species and soil management systems using rotation with soil cover crops for onion crops on the LOM, C, and N contents in the organic matter granulometric fractions in soil macroaggregates and bulk soil.

\section{Material and Methods}

\subsection{Description of the Experiment}

The experiment was implemented in April 2007, in the Experimental Station of the Company of Agricultural Research and Rural Extension of Santa Catarina (EPAGRI), in the municipality of Ituporanga, SC, Brazil. The soil of the area was classified as a Humic Dystrudept (Soil Survey Staff, 2010) and presented the following physical-chemical attributes (evaluated according to Embrapa, 1997) in the $0-10 \mathrm{~cm}$ layer: $410 \mathrm{~g} \mathrm{~kg}^{-1}$ of sand, $264 \mathrm{~g} \mathrm{~kg}^{-1}$ of silt, and 326 $\mathrm{g} \mathrm{kg}^{-1}$ of clay; $\mathrm{pH} \mathrm{H}_{2} \mathrm{O}$ of 6.1 ; exchangeable $\mathrm{Ca}, \mathrm{Mg}, \mathrm{Al}$ of $6.4,2.7$, and $0.0 \mathrm{cmolc} \mathrm{dm}^{-3}$ (extracted with $\mathrm{KCl} 1 \mathrm{~mol} \mathrm{~L}^{-1}$ ), respectively; available $\mathrm{P}$ and $\mathrm{K}$ of 42 and $208 \mathrm{mg} \mathrm{dm}^{-3}$ (extracted with Mehlich-1), respectively; and total organic carbon of $23.08 \mathrm{~g} \mathrm{~kg}^{-1}$.

The climate of the region is Cfa, wet mesothermal, with hot summers, according to the Köppen classification (Alvares et al., 2013), with no defined dry season, presenting an annual average temperature of $17.6^{\circ} \mathrm{C}$ and annual average rainfall depth of $1,400 \mathrm{~mm}$.

A randomized block experimental design was used, with eight treatments and four replications. 
The area of each plot was $8.7 \mathrm{~m}^{2}$, consisted of seven rows with 30 onion plants. The treatments consisted of onion crop systems based on different soil cover crops used for mulching in NTS.

When the experiment was implemented in 2007, the following soil cover crops were sown in the whole area: oat (Avena strigosa Schreb), vetch (Vicia villosa Roth), and oilseed radish (Raphanus raphanistrum subsp. sativus (L.) Domin); subsequently, eight treatments (T1 to T8) were implemented, using soil cover crops and crop sequences (Table 1). The rotation systems and sequence of soil cover crops were modified after 2011, and a treatment under CTS was implemented for comparison with the treatments under NTS (Table 2). The soil preparation in T7 was carried out with one plowing and two harrowing. The sequence of the treatments was repeated after 2014 (Table 2), considering the years 2011, 2012, and 2013, i.e., the sequence of rotation restarted every three years.

Weed, pest, and disease control was carried out using chemical products that are approved for onion crops by the Brazilian Ministry of Agriculture, Livestock, and Food Supply. Approximately 14 days before the onion planting, the plants were killed using glyphosate herbicide $\left(360 \mathrm{~g} \mathrm{~L}^{-1}\right)$ at $4 \mathrm{~L} \mathrm{ha}^{-1}$. Weed control during the onion cycle was carried out using three herbicide applications - two with ioxynil $\left(250 \mathrm{~g} \mathrm{~L}^{-1}\right)$ at $1 \mathrm{~L} \mathrm{ha}^{-1}$ at 35 and 65 days after transplantation (DAT) of the seedlings, and one with clethodim $\left(240 \mathrm{~g} \mathrm{~L}^{-1}\right)$ at $0.4 \mathrm{~L} \mathrm{ha}^{-1}$ at 85 DAT. The control of pests, especially Thrips tabaci Lind, was carried out using three insecticide applications - one with imidacloprid $\left(700 \mathrm{~g} \mathrm{~L}^{-1}\right)$ at $0.1 \mathrm{~kg} \mathrm{ha}^{-1}$ at $30 \mathrm{DAT}$, and two with lambdacyhalothrin $\left(50 \mathrm{~g} \mathrm{~L}^{-1}\right)$ at $0.1 \mathrm{~L} \mathrm{ha}^{-1}$ at approximately 60 and 81 DAT. The control of fungal diseases, mainly mildew (Peronospora destructor) and Alternaria solani, was carried out with six applications of fungicides - four with metalaxyl $\left(40 \mathrm{~g} \mathrm{~L}^{-1}\right)+$ mancozeb $\left(640 \mathrm{~g} \mathrm{~L}^{-1}\right)$ at $35,50,65$, and $80 \mathrm{DAT}$, and two with tebuconazole $\left(200 \mathrm{ml} \mathrm{L}^{-1}\right)+\operatorname{trifloxystrobin}\left(100 \mathrm{ml} \mathrm{L}^{-1}\right)$ at 80 and 94 DAT. All applications were performed using personal protective equipment.

The plant species chosen for the experiment (Tables 1 and 2) were commercial species frequently used in the study region, which present good adaptation, availability of seeds in the market, easy handling, and good dry matter production. The commercial and technical factors of the experiment were combined by adding treatments that were possible to adopt by the farmers, while being useful to elucidate questions related to chemical aspects of the adoption of NTS for onion crops.

The experimental area had been cultivated in a conservation production system since 1995, when the soil $\mathrm{pH}$ was last corrected to 6.0 by liming. The crops in the experiment site had been grown under NTS, except in the treatment T7, which had been under CTS since 2011 for comparison with the treatments under NTS.

Table 1. Species used in rotation with onion crops in different soil tillage system from 2007 to 2010, Ituporanga (SC), Brazil. T=treatments, $\mathrm{T} 1$ = rotation with onion, and maize in no-tillage system (NTS); T2 = rotation with soil cover crops (winter), and biennial onion in NTS; T3 = rotation with maize, winter grasses, and onion in NTS; T4 = rotation with summer legume and annual onion in NTS; T5 = rotation with summer grass, winter grasses, and annual onion in NTS; T6 = rotation with summer legume, winter grass, and annual onion in NTS; T7 = rotation with maize and onion in conventional tillage system (CTS); T8 = rotation with intercrops of 
soil cover crops (summer), and annual onion in NTS

\begin{tabular}{|c|c|c|c|c|c|c|c|c|c|c|c|}
\hline Treatment & \multicolumn{3}{|c|}{2007} & \multicolumn{3}{|c|}{2008} & \multicolumn{2}{|c|}{2009} & \multicolumn{3}{|c|}{2010} \\
\hline & \multicolumn{2}{|c|}{ Winter } & Summer & \multicolumn{2}{|c|}{ Winter } & \multirow{2}{*}{$\begin{array}{c}\text { Summer } \\
\text { Maize }\end{array}$} & \multirow{2}{*}{$\begin{array}{c}\text { Winter } \\
\text { Fallow } \\
\text { Onion }\end{array}$} & \multirow{2}{*}{$\begin{array}{c}\text { Summer } \\
\text { Maize }\end{array}$} & \multicolumn{2}{|c|}{ Winter } & \multirow{2}{*}{$\begin{array}{c}\text { Summer } \\
\text { Maize }\end{array}$} \\
\hline $\mathrm{T} 1$ & $\begin{array}{l}\text { Oat }+\mathrm{V} \\
\text { Oilseed }\end{array}$ & $\begin{array}{l}\text { tch }+ \\
\text { radish }\end{array}$ & Maize & Fallow & Onion & & & & Fallow & Onion & \\
\hline $\mathrm{T} 2$ & $\begin{array}{l}\text { Oat }+ \text { V } \\
\text { Oilseed }\end{array}$ & $\begin{array}{l}\text { tch }+ \\
\text { radish }\end{array}$ & Maize & $\begin{array}{c}\text { Oat }+ \\
\text { Oilseed } \\
\text { radish + } \\
\text { Rye }\end{array}$ & Onion & Sunflower & $\begin{array}{c}\text { Oat + } \\
\text { Vetch }+ \\
\text { Oilseed } \\
\text { radish }\end{array}$ & $\begin{array}{l}\text { Common } \\
\text { bean }\end{array}$ & $\begin{array}{c}\text { Rye + } \\
\text { Oilseed } \\
\text { radish }\end{array}$ & Onion & Maize \\
\hline $\mathrm{T} 3$ & $\begin{array}{l}\text { Oat }+ \text { V } \\
\text { Oilseed }\end{array}$ & $\begin{array}{l}\text { tch }+ \\
\text { radish }\end{array}$ & Maize & $\begin{array}{c}\text { Oat + } \\
\text { Oilseed } \\
\text { radish }\end{array}$ & Onion & Maize & Vetch & Maize & Rye & Onion & Maize \\
\hline $\mathrm{T} 4$ & $\begin{array}{l}\text { Oat }+ \text { V } \\
\text { Oilseed }\end{array}$ & $\begin{array}{l}\text { tch }+ \\
\text { radish }\end{array}$ & Maize & $\begin{array}{c}\text { Oat }+ \\
\text { Oilseed } \\
\text { radish }+ \\
\text { Rye }\end{array}$ & Onion & Velvet bean & Rye & Maize & $\begin{array}{l}\text { Oilseed } \\
\text { radish }\end{array}$ & Onion & Velvet bean \\
\hline T5 & $\begin{array}{c}\text { Oat + } \\
\text { Vetch }+ \\
\text { Oilseed } \\
\text { radish }\end{array}$ & Onion & Pearl Millet & $\begin{array}{l}\text { Oilseed } \\
\text { radish }\end{array}$ & Onion & Pearl Millet & $\begin{array}{c}\text { Oat + } \\
\text { Vetch }+ \\
\text { Oilseed } \\
\text { radish }\end{array}$ & Maize & Barley & Onion & Pearl Millet \\
\hline T6 & $\begin{array}{c}\text { Oat }+ \\
\text { Vetch }+ \\
\text { Oilseed } \\
\text { radish }\end{array}$ & Onion & Jack bean & Rye & Onion & Velvet bean & Onion & $\begin{array}{l}\text { Velvet } \\
\text { bean }\end{array}$ & Rye & Onion & Velvet bean \\
\hline $\mathrm{T} 7$ & $\begin{array}{c}\text { Oat }+ \\
\text { Vetch }+ \\
\text { Oilseed } \\
\text { radish }\end{array}$ & Onion & $\begin{array}{l}\text { Jack bean + } \\
\text { Pearl Millet }\end{array}$ & Oat & Onion & $\begin{array}{l}\text { Showy } \\
\text { rattlebox }\end{array}$ & Rye & Maize & Oat & Onion & $\begin{array}{l}\text { Showy } \\
\text { rattlebox }\end{array}$ \\
\hline $\mathrm{T} 8$ & $\begin{array}{c}\text { Oat }+ \\
\text { Vetch }+ \\
\text { Oilseed } \\
\text { radish }\end{array}$ & Onion & Sunflower & Oat + Rye & Onion & $\begin{array}{c}\text { Sunflower + } \\
\text { Velvet bean + } \\
\text { Pearl Millet }\end{array}$ & Vetch & Maize & $\begin{array}{c}\text { Rye+ } \\
\text { Oat+ } \\
\text { Oilseed } \\
\text { radish }\end{array}$ & Onion & $\begin{array}{c}\text { Pearl Millet+ } \\
\text { Velvet bean+ } \\
\text { Sunflower }\end{array}$ \\
\hline
\end{tabular}

Species = Oat (Avena strigosa Schreb), Onion (Allium cepa L.), Rye (Secale cereale L.), Showy rattlebox (Crotalaria spectabilis Roth), Vetch (Vicia villosa Roth), Common bean (Phaseolus vulgaris L.), Jack bean (Canavalia ensiformis (L.) DC.), Sunflower (Helianthus annuus L.), Maize (Zea mays L.), Pearl Millet (Pennisetum glaucum (L.) R.Br.), Velvet bean (Mucuna pruriens var. utilis (Wall. ex Wight) L.H. Bailey), and Oilseed radish (Raphanus raphanistrum subsp. sativus (L.) Domin), Barley (Hordeum vulgare L.). 
Table 2. Species used in rotation with onion crops from 2011 to 2013. Ituporanga (SC), Brazil. $\mathrm{T}=$ Treatments. $\mathrm{T} 1=$ rotation with onion, and maize in no-tillage system $(\mathrm{NTS}) ; \mathrm{T} 2=$ rotation with soil cover crops (winter), and biennial onion in NTS; T3 = rotation with maize, winter grasses, and onion in NTS; T4 = rotation with summer legume and annual onion in NTS; T5 = rotation with summer grass, winter grasses, and annual onion in NTS; T6 = rotation with summer legume, winter grass, and annual onion in NTS; T7 = rotation with maize and onion in conventional tillage system (CTS); T8 = rotation with intercrops of soil cover crops (summer), and annual onion in NTS

\begin{tabular}{|c|c|c|c|c|c|c|c|c|c|}
\hline \multirow[t]{2}{*}{ Treatment } & \multicolumn{3}{|c|}{2011} & \multicolumn{3}{|c|}{2012} & \multicolumn{3}{|c|}{2013} \\
\hline & \multicolumn{2}{|c|}{ Winter } & \multirow{2}{*}{$\begin{array}{c}\text { Summer } \\
\text { Maize }\end{array}$} & \multicolumn{2}{|c|}{ Winter } & Summer & \multicolumn{2}{|c|}{ Winter } & Summer \\
\hline $\mathrm{T} 1$ & Fallow & Onion & & Fallow & Onion & Maize & Fallow & Onion & Maize \\
\hline $\mathrm{T} 2$ & \multicolumn{2}{|c|}{ Vetch } & Maize & $\begin{array}{c}\text { Rye+ } \\
\text { Oilseed } \\
\text { radish }\end{array}$ & Onion & Maize & \multicolumn{2}{|c|}{$\begin{array}{c}\text { Oilseed radish } \\
+\end{array}$} & $\begin{array}{c}\text { Common } \\
\text { bean }\end{array}$ \\
\hline $\mathrm{T} 3$ & Rye & Onion & Maize & Oat & Onion & Maize & Rye & Onion & Maize \\
\hline $\mathrm{T} 4$ & $\begin{array}{l}\text { Fallow } \\
\text { Onion }\end{array}$ & & $\begin{array}{l}\text { Velvet } \\
\text { bean }\end{array}$ & $\begin{array}{l}\text { Fall } \\
\text { Oni }\end{array}$ & $\begin{array}{l}\text { ow } \\
\text { lon }\end{array}$ & $\begin{array}{l}\text { Velvet } \\
\text { bean }\end{array}$ & $\begin{array}{l}\text { Fal } \\
\text { On }\end{array}$ & $\begin{array}{l}\text { low } \\
\text { ion }\end{array}$ & $\begin{array}{l}\text { Velvet } \\
\text { bean }\end{array}$ \\
\hline T5 & Rye & Onion & $\begin{array}{l}\text { Pearl } \\
\text { Millet }\end{array}$ & Oat & Onion & $\begin{array}{l}\text { Pearl } \\
\text { Millet }\end{array}$ & Rye & Onion & $\begin{array}{l}\text { Pearl } \\
\text { Millet }\end{array}$ \\
\hline T6 & Rye & Onion & $\begin{array}{l}\text { Velvet } \\
\text { bean }\end{array}$ & Rye & Onion & $\begin{array}{l}\text { Velvet } \\
\text { bean }\end{array}$ & Rye & Onion & $\begin{array}{l}\text { Velvet } \\
\text { bean }\end{array}$ \\
\hline $\mathrm{T} 7$ & Fallow & Onion & Maize & Fallow & Onion & Maize & Fallow & Onion & Maize \\
\hline & & & $\begin{array}{c}\text { Pearl } \\
\text { Millet+ }\end{array}$ & & & $\begin{array}{c}\text { Pearl } \\
\text { Millet+ }\end{array}$ & & & $\begin{array}{c}\text { Pearl } \\
\text { Millet+ }\end{array}$ \\
\hline $\mathrm{T} 8$ & Fallow & Onion & $\begin{array}{l}\text { Velvet } \\
\text { bean+ }\end{array}$ & Fallow & Onion & $\begin{array}{l}\text { Velvet } \\
\text { bean+ }\end{array}$ & Fallow & Onion & $\begin{array}{l}\text { Velvet } \\
\text { bean+ }\end{array}$ \\
\hline & & & Sunflower & & & Sunflower & & & Sunflower \\
\hline
\end{tabular}

Species = Oat (Avena strigosa Schreb), Onion (Allium cepa L.), Rye (Secale cereale L.), Vetch 
(Vicia villosa Roth), Common bean (Phaseolus vulgaris L.), Sunflower (Helianthus annuus L.), Maize (Zea mays L.), Pearl Millet (Pennisetum glaucum (L.) R.Br.), Velvet bean (Mucuna pruriens var. utilis (Wall. ex Wight) L.H. Bailey) and Oilseed radish (Raphanus raphanistrum subsp. sativus (L.) Domin).

During the experiment, the soil was fertilized only for the onion and maize crops, according to the recommendations for these crops (CQFS-RS/SC, 2004). Annual soil fertilization for onion crops consisted of $75 \mathrm{~kg} \mathrm{ha}^{-1}$ of $\mathrm{N}, 120 \mathrm{~kg} \mathrm{ha}^{-1}$ of $\mathrm{P}_{2} \mathrm{O}_{5}$, and $60 \mathrm{~kg} \mathrm{ha}^{-1}$ of $\mathrm{K}_{2} \mathrm{O}$, with all $\mathrm{P}$ and $\mathrm{K}$ and $15 \mathrm{~kg} \mathrm{ha}^{-1} \mathrm{~N}$ applied at planting; the remaining $\mathrm{N}$ was applied at 45, 65, and 85 DAT. Phosphorus contents in the area in 2010 were very high, thus, the soil fertilization consisted of $50 \mathrm{~kg} \mathrm{ha}^{-1}$ of $\mathrm{P}$ and, in the following onion crop, it consisted of $80 \mathrm{~kg} \mathrm{ha}^{-1}$ of P. Soil fertilization with $\mathrm{P}$ and $\mathrm{K}$ was not performed for maize crops due to the high contents of these nutrients in the soil; $\mathrm{N}$ fertilization consisted of $90 \mathrm{~kg} \mathrm{ha}^{-1}$ of $\mathrm{N}$ (urea) when the maize plants had six to eight leaves.

Before the onion seedlings were manually transplanted, the soil cover crops were killed and furrows were opened with a machine adapted for planting of onion in NTS. The onion cultivar used was the Empasc 352 (Bola Precoce); the spacing used was $0.40 \mathrm{~m}$ between rows and 0.10 $\mathrm{m}$ between plants, with seven onion rows per plot.

\subsection{Dry Matter of Soil Cover Crops and Onion Yield}

The shoot dry matter (SDM) yield of the soil cover crops was evaluated in the same year that the soil samples were collected (2016). The SDM yield of the natural vegetation was evaluated together with the soil cover crops; the predominant species of this natural vegetation were from the following botanical families: Amaranthaceae (10\%), Asteraceae, Caryophyllaceae, Compositae (10\%), Convolvulaceae, Cruciferae, Cyperaceae (25\%), Euphorbiaceae, Fabaceae, Lamiaceae (10\%), Leguminosae, Liliaceae, Malvaceae, Oxalidaceae (10\%), Plantaginaceae, Poaceae, and Polygonaceae (20\%). The SDM yield of maize (Table 3) in the treatments containing this species (T1, T2, T3, and T7) was also evaluated. The average onion bulb yields found from 2011 to 2016 for each treatment are shown in Table 4.

Table 3. Shoot dry matter (SDM) yield of the soil cover crops, natural vegetation, and maize in rotation with onion crops under no-tillage and conventional tillage systems in 2016

\begin{tabular}{ccccccccc}
\hline \multirow{2}{*}{$\begin{array}{c}\text { SDM yield } \\
\left(\mathrm{Mg} \mathrm{ha}^{-1}\right)\end{array}$} & $\mathrm{T} 1$ & $\mathrm{~T} 2$ & $\mathrm{~T} 3$ & $\mathrm{~T} 4$ & $\mathrm{~T} 5$ & $\mathrm{~T} 6$ & $\mathrm{~T} 7$ & $\mathrm{~T} 8$ \\
\cline { 2 - 8 } & & & & & & & & \\
\hline 2016 & 5.97 & 9.73 & 10.5 & 4.01 & 11.6 & 7.58 & 4.76 & 11.0 \\
\hline $\begin{array}{c}\text { SDM yield } \\
\text { of maize }\end{array}$ & $\mathrm{T} 1$ & $\mathrm{~T} 2$ & $\mathrm{~T} 3$ & $\mathrm{~T} 4$ & $\mathrm{~T} 5$ & $\mathrm{~T} 6$ & $\mathrm{~T} 7$ & $\mathrm{~T} 8$ \\
\cline { 2 - 8 } & & & & $\left(\mathrm{Mg} \mathrm{ha}^{-1}\right)$ & & \\
\hline
\end{tabular}


$\mathrm{T} 1=$ rotation with onion and maize in no-tillage system $(\mathrm{NTS}) ; \mathrm{T} 2=$ rotation with soil cover crops (winter) and biennial onion in NTS; T3 = rotation with maize, winter grasses, and onion in NTS; T4 = rotation with summer legume and annual onion in NTS; T5 = rotation with summer grass, winter grasses, and annual onion in NTS; T6 = rotation with summer legume, winter grass, and annual onion in NTS; T7 = rotation with maize and onion in conventional tillage system (CTS); T8 = rotation with intercrops of soil cover crops (summer) and annual onion in NTS.

Table 4. Average onion bulb yield of crops under no-tillage and conventional tillage systems, including crop rotations, from 2011 to 2016 crop seasons

\begin{tabular}{ccccccccc}
\hline Treatments & T1 & T2 & T3 & T4 & T5 & T6 & T7 & T8 \\
\hline Onion bulb yield $\left(\mathrm{Mg} \mathrm{ha}^{-1}\right)$ & 32.6 & 35.4 & 36.4 & 33.2 & 34.7 & 33.4 & 29.2 & 34.8 \\
\hline
\end{tabular}

$\mathrm{T} 1=$ rotation with onion and maize in no-tillage system $(\mathrm{NTS}) ; \mathrm{T} 2=$ rotation with soil cover crops (winter) and biennial onion in NTS; T3 = rotation with maize, winter grasses, and onion in NTS; T4 = rotation with summer legume and annual onion in NTS; T5 = rotation with summer grass, winter grasses, and annual onion in NTS; T6 = rotation with summer legume, winter grass, and annual onion in NTS; T7 = rotation with maize and onion in conventional tillage system (CTS); T8 = rotation with intercrops of soil cover crops (summer) and annual onion in NTS.

\subsection{Soil Sampling and Analyses}

In September 2016, nine years after the beginning of the experiment, undisturbed and disturbed soil samples were collected in each plot. A $40 \times 40 \times 40 \mathrm{~cm}$ trench was opened between the onion rows in each plot using a spade, and samples were collected from the $0-5,5-10$, and 10-20 cm soil layers. The samples were then placed in plastic bags and sent to the Laboratory of Soil Management and Classification of the Federal University of Santa Catarina, where they were air-dried. Undisturbed samples were manually disaggregated following cracks or weak points, and sieved in $8.00 \mathrm{~mm}$ and $2.00 \mathrm{~mm}$ mesh sieves to obtain the soil aggregate indexes (Giumbelli et al., 2020). In general, each undisturbed sample weighed approximately 900 to $1,000 \mathrm{~g}$. The aggregates with diameters of $8.00 \mathrm{~mm}>\varnothing \geq 2.0 \mathrm{~mm}$, which were used for the evaluation of chemical properties of soils, represented approximately $60 \%$ of the total weight of soils under NTS. The aggregates of soils under CTS did not exceed $30 \%$ to $35 \%$ of the total soil weight. The amounts referring to aggregate stability and aggregation indexes are described in Giumbelli et al. (2020). Disturbed samples were sieved in a $2.00 \mathrm{~mm}$ mesh sieve to obtain the air-dried fine earth (bulk soil). The following analyses were performed for the soil aggregates and bulk soil.

\subsection{Organic Matter Granulometric Fractionation}

The SOM granulometric fractionation was carried out for macroaggregates and bulk soil 
samples, using the methodology described by Cambardella and Elliott (1992). Twenty grams of bulk soil and macroaggregates and $60 \mathrm{~mL}$ of a sodium hexametaphosphate solution $(5 \mathrm{~g}$ $\mathrm{L}^{-1}$ ) were used. The samples were shaken for 15 hours on a shaker and the suspension was passed through a $53 \mu \mathrm{m}$ mesh sieve using water jets. The material retained in the sieve, which consists of POC and PON, was dried in an oven at $60{ }^{\circ} \mathrm{C}$, weighed, ground in a porcelain mortar, passed through a 100-mesh sieve $(150 \mu \mathrm{m})$, and analyzed in an autoanalyzer at $900{ }^{\circ} \mathrm{C}$ (CHN-600 Carlo Erba EA-1110, Italy) at the Center for Nuclear Energy in Agriculture (CENA) of the University of São Paulo (USP), in Piracicaba, SP, Brazil. The material that passed through the $53 \mu \mathrm{m}$ mesh sieve, which consisted of MOC and MON, was evaluated by the difference between COT and NOT, and POC and PON.

\subsection{Light Organic Matter (LOM) Contents}

LOM was analyzed only in the bulk soil because there was not enough macroaggregates in the CTS. Fifty grams of bulk soil were placed in $250 \mathrm{~mL}$ beakers and $100 \mathrm{~mL}$ of a $\mathrm{NaOH}$ solution $(0.1 \mathrm{~mol} \mathrm{L-1})$ was added and left to rest overnight. The suspension was then shaken with a glass rod and the material was passed through a $0.25 \mathrm{~mm}$ mesh sieve to remove the clay and silt fractions (Anderson \& Ingram, 1988). The material retained in the sieve (LOM and sand) was transferred to a beaker, which was filled with water. The floated material was carefully passed through a $0.25 \mathrm{~mm}$ mesh sieve to separate the LOM from the sand fraction. Water was added to the beaker, which was manually shaken to resuspend the remaining LOM and slowly pour the material in the $0.25 \mathrm{~mm}$ mesh sieve. This procedure was repeated until all the material that floated with the water shaken was removed. The material withheld in the sieve (LOM) was transferred to previously weighed aluminum containers and taken to an oven at $60{ }^{\circ} \mathrm{C}$ for 72 hours until constant weight. $\mathrm{C}$ and $\mathrm{N}$ contents in the LOM were then determined by the dry combustion method in a $\mathrm{C}$ and $\mathrm{N}$ autoanalyzer at $900{ }^{\circ} \mathrm{C}(\mathrm{CHN}-600$ Carlo Erba EA - 1110, Italy), in the CENA-USP, Piracicaba, SP, Brazil. The C to $\mathrm{N}$ ratio $(\mathrm{C} / \mathrm{N})$ was then calculated.

The LOM weight data and $\mathrm{C}$ and $\mathrm{N}$ contents were used to correct each element, using the equation: Corrected LOM-C content $(g \mathrm{~kg}-1)=[L O M-C(g \mathrm{~kg}-1) \times$ soil LOM $(\mathrm{g} \mathrm{kg-1})] /$ 1000. The nitrogen correction was carried out in the same way, considering the $\mathrm{N}$ contents instead of C. These corrections provided carbon and nitrogen contents added to the soil as LOM.

\subsection{Statistical Analyses}

The results were analyzed for normality and homogeneity of the data by the Lilliefors (Lilliefors, 1967) and Bartlet (Bartlett, 1937) tests, respectively. The data were subjected to analysis of variance (F test) and, when the effects were significant, the means were compared by the Scott-Knott test at 5\% probability, using the software Sisvar 5.6. Statistical analyses were performed for the eight treatments, macroaggregates, and bulk soil. Subsequently, the data of each treatment were subjected to statistical analysis, independently, and the results of the macroaggregates and bulk soil were compared by the LSD test at 5\%.

\section{Results}


3.1 POC and MOC in the Bulk Soil and Macroaggregates

2021, Vol. 9, No. 1

In the bulk soil, the POC contents found were equal in the $0-5 \mathrm{~cm}$ layer of all treatments under NTS; T7 presented the lowest POC contents. The highest POC contents in the bulk soil were found in T2 and T6 in the 5-10 cm layer; and in T2, T3, T5, and T8 in the 10-20 cm layer (Table 5).

In aggregates in the $0-5 \mathrm{~cm}$ layer, the highest POC contents were found in $\mathrm{T} 2$ and $\mathrm{T} 3$, and the lowest in T7. Among the treatments under NTS, T1 presented the lowest POC contents. Considering the aggregates in the 5-10 cm layer, only T5 differed from the other treatments, presenting the highest POC contents. In the 10-20 cm layer, the highest POC contents were found in T5, T7, and T8 (Table 5).

Considering the bulk soil, the treatments T4 and T5 presented the highest MOC contents in the $0-5 \mathrm{~cm}$ layer; T4 presented the highest MOC contents in the 5-10 $\mathrm{cm}$ layer; and T4, T6, and T8 presented the highest MOC contents in the 10-20 cm layer. T1 presented the lowest MOC contents in the bulk of all layers evaluated (Table 5).

Considering the aggregates, the treatments $\mathrm{T} 1, \mathrm{~T} 2, \mathrm{~T} 4, \mathrm{~T} 5$, and $\mathrm{T} 6$ presented the highest MOC contents in the 0-5 cm layer; T5 had the highest contents in the 5-10 cm layer; and T1 and T8 had the highest contents in the 10-20 cm layer. In aggregates of the 0-5 cm layer, T7presented the lowest MOC contents; in the 5-10 cm layer, T1, T3, T6, and T7 presented the lowest contents; and in the 10-20 cm layer, T7 had the lowest MOC contents (Table 5).

\subsection{PON and MON in Bulk soil and Soil Macroaggregates}

In the bulk soil, the highest PON contents in the $0-5 \mathrm{~cm}$ layer were found in T2, T3, T4, T5, $\mathrm{T} 6$, and $\mathrm{T} 8$, varying from 0.605 to $0.747 \mathrm{~g} \mathrm{~kg}^{-1}$. In the $5-10 \mathrm{~cm}$ layer, T5 showed the highest PON content $\left(0.317 \mathrm{~g} \mathrm{~kg}^{-1}\right)$, whereas no significant difference was found among the rest of the treatments. T5, T7, and T8 in the 10-20 cm layer showed the highest values, with no significant difference from the other treatments. The lowest PON contents in the $0-5 \mathrm{~cm}$ layer was found in T7, followed by T1 (Table 6).

In aggregates, T6 presented the highest PON contents in the $0-5$ and $5-10 \mathrm{~cm}$ soil layers, whereas T7 presented the lowest in the $0-5 \mathrm{~cm}$ layer, and T7 and T1 had the lowest contents in the 5-10 cm layer. No significant difference between treatments was found for the 10-20 $\mathrm{cm}$ soil layer. Among the treatments under NTS, T3 $(0-5 \mathrm{~cm}$ layer $)$ and T3 and T1 $(5-10 \mathrm{~cm}$ layer) presented the lowest PON contents (Table 6).

In the bulk soil, the highest MON contents in the $0-5 \mathrm{~cm}$ layer were found in the treatments T4, T5, T6, and T8; and the lowest in T3 and T7. The highest MON contents in the 5-10 cm layer was found in $\mathrm{T} 5$ and $\mathrm{T} 8$, with no significant difference found among the rest treatments. In the 10-20 cm layer, the highest MON contents were found in T1, and the lowest in T2, T4, T7, and T8 (Table 6). 
Table 5. Particulate organic carbon (POC) and mineral-associated organic carbon (MOC) in soils under no-tillage and conventional tillage systems for onion crops in rotation with crops and soil cover plants, Ituporanga, SC, Brazil

\begin{tabular}{|c|c|c|c|c|c|c|}
\hline \multirow{3}{*}{ Treatment } & \multicolumn{3}{|c|}{$\mathrm{POC}\left(\mathrm{g} \mathrm{kg}^{-1}\right)$} & \multicolumn{3}{|c|}{$\operatorname{MOC}\left(\mathrm{g} \mathrm{kg}^{-1}\right)$} \\
\hline & Bulk soil & Aggregates & CV\% & Bulk soil & Aggregates & CV\% \\
\hline & \multicolumn{6}{|c|}{ Soil 0-5 cm layer } \\
\hline T1 & 9.34Aa & $6.62 \mathrm{Cb}$ & 7.65 & 21.31Eb & $27.44 \mathrm{Aa}$ & 6.4 \\
\hline $\mathrm{T} 2$ & $8.01 \mathrm{Aa}$ & 9.15Aa & 5.92 & $26.01 \mathrm{Cb}$ & $29.07 \mathrm{Aa}$ & 3.62 \\
\hline $\mathrm{T} 3$ & $10.53 \mathrm{Aa}$ & $8.70 \mathrm{Ba}$ & 18.15 & $29.68 \mathrm{Ba}$ & $24.55 \mathrm{Bb}$ & 3.9 \\
\hline $\mathrm{T} 4$ & $9.32 \mathrm{Aa}$ & $7.74 \mathrm{Bb}$ & 7.44 & 33.08Aa & $28.76 \mathrm{Ab}$ & 3.32 \\
\hline T5 & $9.40 \mathrm{Aa}$ & $8.16 \mathrm{Ba}$ & 12.79 & 32.49Aa & $29.85 \mathrm{Ab}$ & 2.47 \\
\hline T6 & $10.59 \mathrm{Aa}$ & 8.30Bb & 6.58 & $27.03 \mathrm{Cb}$ & 29.88Aa & 4.89 \\
\hline $\mathrm{T} 7$ & 4.55Ba & 4.05Da & 7.20 & 24.16Da & 23.05Cb & 0.78 \\
\hline $\mathrm{T} 8$ & 9.79Aa & 8.30Ba & 10.02 & $27.72 \mathrm{Ca}$ & $25.48 \mathrm{Bb}$ & 4.37 \\
\hline $\mathrm{CV} \%$ & 11.47 & 10.55 & & 3.6 & 4.32 & \\
\hline \multicolumn{7}{|c|}{ Soil 5-10 cm layer } \\
\hline T1 & $3.27 \mathrm{Ba}$ & $2.43 \mathrm{Bb}$ & 11.38 & $21.00 \mathrm{Fb}$ & 22.75Ca & 1.00 \\
\hline $\mathrm{T} 2$ & 4.77Aa & $3.19 \mathrm{Ab}$ & 10.52 & $24.45 \mathrm{Ea}$ & $25.84 \mathrm{Ba}$ & 3.38 \\
\hline T3 & $3.80 \mathrm{Ba}$ & $2.98 \mathrm{Bb}$ & 6.38 & $26.79 \mathrm{Ca}$ & $23.45 \mathrm{Cb}$ & 3.42 \\
\hline $\mathrm{T} 4$ & 3.49Ba & $2.77 \mathrm{Bb}$ & 0.71 & 30.17Aa & $25.66 \mathrm{Bb}$ & 1.96 \\
\hline T5 & 3.89Ba & 3.17Ab & 13.27 & $24.45 \mathrm{~Eb}$ & 29.11Aa & 4.02 \\
\hline T6 & 4.57Aa & $2.96 \mathrm{Bb}$ & 6.64 & $24.87 \mathrm{Ea}$ & $21.96 \mathrm{Cb}$ & 4.06 \\
\hline $\mathrm{T} 7$ & $3.16 \mathrm{Ba}$ & $2.86 \mathrm{Ba}$ & 7.20 & 25.91Da & $24.28 \mathrm{Cb}$ & 2.69 \\
\hline $\mathrm{T} 8$ & 3.84Ba & $2.67 \mathrm{Bb}$ & 5.98 & $27.86 \mathrm{Ba}$ & $27.19 \mathrm{Bb}$ & 1.25 \\
\hline CV\% & 11.15 & 13.49 & & 2.73 & 8.03 & \\
\hline \multicolumn{7}{|c|}{ Soil 10-20 cm layer } \\
\hline $\mathrm{T} 1$ & $2.02 \mathrm{Ba}$ & $1.47 \mathrm{Bb}$ & 6.97 & 19.26Eb & 22.71Aa & 6.71 \\
\hline $\mathrm{T} 2$ & $2.20 \mathrm{Aa}$ & $1.57 \mathrm{Bb}$ & 4.89 & $22.59 \mathrm{Ba}$ & $19.83 \mathrm{Cb}$ & 2.09 \\
\hline T3 & $2.47 \mathrm{Aa}$ & $1.70 \mathrm{Bb}$ & 7.27 & $21.87 \mathrm{Ca}$ & $21.21 \mathrm{Ba}$ & 1.96 \\
\hline $\mathrm{T} 4$ & $1.97 \mathrm{Ba}$ & $1.60 \mathrm{Bb}$ & 11.13 & 24.39Aa & $20.46 \mathrm{Cb}$ & 1.65 \\
\hline T5 & 2.37Aa & $1.90 \mathrm{Ab}$ & 6.94 & $20.42 \mathrm{Da}$ & $20.73 \mathrm{Ca}$ & 1.77 \\
\hline T6 & $1.89 \mathrm{Ba}$ & $1.64 \mathrm{Bb}$ & 2.29 & 23.90Aa & $21.34 \mathrm{Bb}$ & 3.43 \\
\hline $\mathrm{T} 7$ & $2.12 \mathrm{Ba}$ & $1.83 \mathrm{Aa}$ & 11.46 & $21.87 \mathrm{Ca}$ & 18.65Db & 4.17 \\
\hline $\mathrm{T} 8$ & $2.29 \mathrm{Aa}$ & $1.97 \mathrm{Ab}$ & 6.32 & 24.04Aa & 22.90Aa & 3.75 \\
\hline CV\% & 7.35 & 8.13 & & 3.03 & 3.98 & \\
\hline
\end{tabular}

Means followed by the same uppercase letter in the columns are not significantly different (comparing treatments, for bulk soil and aggregates) by the Scott-Knott test $(p<0.05)$; means followed by the same lowercase letter in the rows are not significantly different (comparing bulk soil and aggregates, for each treatment), by the t-LSD test $(p<0.05)$. CV $=$ coefficient of variation. $\mathrm{T} 1=$ rotation with onion, and maize in no-tillage system (NTS); T2 = rotation with soil cover crops (winter), and biennial onion in NTS; T3 = rotation with maize, winter grasses, and onion in NTS; T4 = rotation with summer legume and annual onion in NTS; T5 = rotation with summer grass, winter grasses, and annual onion in NTS; T6 = rotation with summer legume, winter grass, and annual onion in NTS; T7 = rotation with maize and onion 
in conventional tillage system (CTS); T8 = rotation with intercrops of soil cover crops (summer), and annual onion in NTS.

Table 6. Particulate organic nitrogen (PON) and mineral-associated organic nitrogen (MON) in soils under no-tillage and conventional tillage systems for onion crops in rotation with crops and soil cover plants, Ituporanga, SC, Brazil

\begin{tabular}{|c|c|c|c|c|c|c|}
\hline \multirow{3}{*}{ Treatment } & \multicolumn{3}{|c|}{ PON $\left(\mathrm{g} \mathrm{kg}^{-1}\right)$} & \multicolumn{3}{|c|}{$\operatorname{MON}\left(\mathrm{g} \mathrm{kg}^{-1}\right)$} \\
\hline & \multirow{2}{*}{\multicolumn{6}{|c|}{ Soil 0-5 cm layer }} \\
\hline & & & & & & \\
\hline $\mathrm{T} 1$ & $0.447 \mathrm{Bb}$ & $0.640 \mathrm{Ba}$ & 9.16 & $2.507 \mathrm{Ba}$ & 2.007Eb & 6.74 \\
\hline $\mathrm{T} 2$ & $0.672 \mathrm{Ab}$ & $0.750 \mathrm{Ba}$ & 5.47 & $2.600 \mathrm{Ba}$ & $2.227 \mathrm{Db}$ & 4.26 \\
\hline $\mathrm{T} 3$ & $0.642 \mathrm{Aa}$ & $0.482 \mathrm{Ca}$ & 23.03 & $2.117 \mathrm{Cb}$ & $2.920 \mathrm{Ba}$ & 1.06 \\
\hline $\mathrm{T} 4$ & $0.655 \mathrm{Ab}$ & $0.772 \mathrm{Ba}$ & 8.44 & 2.727Ab & $3.225 \mathrm{Aa}$ & 4.54 \\
\hline T5 & $0.605 \mathrm{Aa}$ & $0.712 \mathrm{Ba}$ & 13.26 & $2.750 \mathrm{Ab}$ & $2.930 \mathrm{Ba}$ & 2.83 \\
\hline T6 & $0.707 \mathrm{Ab}$ & 0.972Aa & 6.06 & 2.932Aa & $2.642 \mathrm{Cb}$ & 4.43 \\
\hline $\mathrm{T} 7$ & $0.260 \mathrm{Ca}$ & $0.295 \mathrm{Da}$ & 8.19 & 2.057Ca & 2.017Ea & 1.90 \\
\hline $\mathrm{T} 8$ & $0.747 \mathrm{Aa}$ & $0.737 \mathrm{Ba}$ & 8.96 & 2.857Aa & $2.650 \mathrm{Ca}$ & 4.70 \\
\hline $\mathrm{CV} \%$ & 11.35 & 10.95 & & 4.70 & 3.60 & \\
\hline \multicolumn{7}{|c|}{ Soil 5-10 cm layer } \\
\hline T1 & $0.150 \mathrm{Bb}$ & 0.197Da & 13.45 & $1.967 \mathrm{Ba}$ & 1.897Ea & 3.83 \\
\hline $\mathrm{T} 2$ & $0.207 \mathrm{Bb}$ & $0.332 \mathrm{Ba}$ & 13.65 & $2.080 \mathrm{Ba}$ & $2.192 \mathrm{Da}$ & 4.35 \\
\hline $\mathrm{T} 3$ & $0.195 \mathrm{Bb}$ & $0.255 \mathrm{Ca}$ & 10.26 & $2.125 \mathrm{Ba}$ & $2.297 \mathrm{Ca}$ & 4.76 \\
\hline $\mathrm{T} 4$ & $0.195 \mathrm{Bb}$ & $0.312 \mathrm{Ba}$ & 4.48 & $2.027 \mathrm{Bb}$ & 2.582Aa & 3.25 \\
\hline T5 & 0.317Aa & $0.280 \mathrm{Ba}$ & 26.17 & $2.247 \mathrm{Aa}$ & $2.157 \mathrm{Da}$ & 3.51 \\
\hline T6 & $0.220 \mathrm{Bb}$ & $0.390 A \mathbf{a}$ & 8.67 & $2.062 \mathrm{Bb}$ & $2.305 \mathrm{Ca}$ & 3.64 \\
\hline $\mathrm{T} 7$ & $0.170 \mathrm{Ba}$ & $0.197 D a$ & 9.57 & $2.075 \mathrm{Ba}$ & $2.062 \mathrm{Da}$ & 1.83 \\
\hline $\mathrm{T} 8$ & $0.212 \mathrm{Bb}$ & $0.285 \mathrm{Ba}$ & 11.10 & $2.200 \mathrm{Ab}$ & $2.442 \mathrm{Ba}$ & 2.40 \\
\hline $\mathrm{CV} \%$ & 17.8 & 12.3 & & 3.66 & 3.47 & \\
\hline \multicolumn{7}{|c|}{ Soil 10-20 cm layer } \\
\hline $\mathrm{T} 1$ & $0.075 \mathrm{Bb}$ & $0.110 \mathrm{Aa}$ & 19.24 & 1.902Aa & $1.542 \mathrm{Cb}$ & 7.51 \\
\hline $\mathrm{T} 2$ & $0.092 \mathrm{Bb}$ & $0.155 \mathrm{Aa}$ & 26.34 & $1.590 \mathrm{Cb}$ & $1.755 \mathrm{Ba}$ & 2.06 \\
\hline $\mathrm{T} 3$ & $0.085 \mathrm{Bb}$ & $0.170 \mathrm{Aa}$ & 18.39 & $1.757 \mathrm{Ba}$ & $1.725 \mathrm{Ba}$ & 3.65 \\
\hline $\mathrm{T} 4$ & $0.092 \mathrm{Bb}$ & $0.137 \mathrm{Aa}$ & 20.55 & $1.612 \mathrm{Cb}$ & 1.900Aa & 2.14 \\
\hline T5 & $0.112 \mathrm{Ab}$ & $0.140 \mathrm{Aa}$ & 10.60 & $1.710 \mathrm{Ba}$ & $1.710 \mathrm{Ba}$ & 2.82 \\
\hline T6 & $0.090 \mathrm{Bb}$ & $0.145 \mathrm{Aa}$ & 23.82 & $1.770 \mathrm{Ba}$ & 1.817Aa & 3.38 \\
\hline $\mathrm{T} 7$ & 0.122Aa & $0.117 \mathrm{Aa}$ & 10.49 & $1.590 \mathrm{Ca}$ & $1.550 \mathrm{Ca}$ & 7.22 \\
\hline $\mathrm{T} 8$ & 0.137Ab & $0.160 \mathrm{Aa}$ & 17.52 & $1.660 \mathrm{Cb}$ & 1.917Aa & 4.00 \\
\hline $\mathrm{CV} \%$ & 15.89 & 20.12 & & 4.90 & 4.02 & \\
\hline
\end{tabular}

Means followed by the same uppercase letter in the columns are not significantly different (comparing treatments, for bulk soil and aggregates) by the Scott-Knott test $(p<0.05)$; means followed by the same lowercase letter in the rows are not significantly different (comparing bulk soil and aggregates, for each treatment), by the t-LSD test $(p<0.05)$. CV $=$ coefficient of variation. $\mathrm{T} 1=$ rotation with onion, and maize in no-tillage system (NTS); T2 = rotation with soil cover crops (winter), and biennial onion in NTS; T3 = rotation with maize, winter grasses, and onion in NTS; T4 = rotation with summer legume and annual onion in NTS; T5 = rotation with summer grass, winter grasses, and annual onion in NTS; T6 = rotation with 
summer legume, winter grass, and annual onion in NTS; T7 = rotation with maize and onion in conventional tillage system (CTS); T8 = rotation with intercrops of soil cover crops (summer), and annual onion in NTS.

In aggregates, the highest MON contents in the $0-5$ and 5-10 cm layers were found in T4, and the highest contents in the 10-20 cm layer were found in T4, T6, and T8. T1 and T7 presented the lowest MON contents in the 0-5 cm layer; T1 presented the lowest one in the 10-20 cm layer, followed by T2, T5, and T7; and T1 and T7 had the lowest contents in the 10-20 cm layer (Table 6).

\subsection{Light Organic Matter (LOM), LOM-C, and LOM-N Contents}

The highest LOM contents were found in the treatment $\mathrm{T} 2$, in the $0-5$ and 5-10 $\mathrm{cm}$ soil layers; and the lowest in T7 $(0-10 \mathrm{~cm})$ and T1 $(5-10 \mathrm{~cm})$. In the 10-20 cm layer, T5, T6, and T8 had the highest LOM contents, and T4 had the lowest. The higher LOM-C contents were found in $\mathrm{T} 2$ and $\mathrm{T} 8$, and the lowest in $\mathrm{T} 7$, in the $0-5 \mathrm{~cm}$ soil layer. In the $5-10 \mathrm{~cm}$ layer, only $\mathrm{T} 2$ was different from the other treatments, presenting the highest LOM-C contents. In the 10-20 cm layer, T2 and T4 presented the lowest LOM-C contents, followed by T3 and T7; and the highest contents were found in T6, followed by T1 and T5 (Table 7).

T4 and T8 presented the highest LOM-N contents, followed by T2 and T6; and T7 had the lowest, followed by T5, in the $0-5 \mathrm{~cm}$ layer. In the $5-10 \mathrm{~cm}$ layer, T4 had the highest, and T7 had the lowest LOM-N contents; T1 and T5 had lower N contents than T2, T3, T6, and T8. In the 10-20 cm layer, T8 and T5 had the highest, and T2, T3, and T4 had the lowest LOM-N contents (Table 7).

Table 7. Light organic matter (LOM), and carbon (C) and nitrogen (N) contents, and LOM-C/N in soils under no-tillage and conventional tillage systems for onion crops in rotation with crops and soil cover plants, Ituporanga, SC, Brazil

\begin{tabular}{|c|c|c|c|c|}
\hline Treatment & LOM & $\mathrm{C}$ & $\mathrm{N}$ & LOM-C/N \\
\hline \multicolumn{5}{|c|}{$\left(\mathrm{g} \mathrm{kg}^{-1}\right)$} \\
\hline \multicolumn{5}{|c|}{ Soil 0-5 $\mathrm{cm}$ layer } \\
\hline T1 & $6.55 \mathrm{~B}$ & $1.45 \mathrm{~B}$ & $0.090 \mathrm{C}$ & 16.17B \\
\hline $\mathrm{T} 2$ & $10.55 \mathrm{~A}$ & 1.77A & $0.116 \mathrm{~B}$ & $15.24 \mathrm{C}$ \\
\hline $\mathrm{T} 3$ & $5.60 \mathrm{~B}$ & $1.38 \mathrm{~B}$ & $0.085 \mathrm{C}$ & $16.21 \mathrm{~B}$ \\
\hline $\mathrm{T} 4$ & $5.80 \mathrm{~B}$ & $1.44 \mathrm{~B}$ & $0.129 A$ & $11.17 F$ \\
\hline T5 & $5.05 \mathrm{~B}$ & $1.38 \mathrm{~B}$ & $0.076 \mathrm{D}$ & $18.20 \mathrm{~A}$ \\
\hline T6 & $5.30 \mathrm{~B}$ & $1.40 \mathrm{~B}$ & $0.103 \mathrm{~B}$ & $13.65 \mathrm{D}$ \\
\hline $\mathrm{T} 7$ & $3.20 \mathrm{C}$ & $0.69 \mathrm{C}$ & $0.038 E$ & 18.03A \\
\hline $\mathrm{T} 8$ & $6.05 \mathrm{~B}$ & $1.72 \mathrm{~A}$ & $0.137 A$ & $12.47 \mathbf{E}$ \\
\hline $\mathrm{CV} \%$ & 17.55 & 9.15 & 2.15 & 3.03 \\
\hline \multicolumn{5}{|c|}{ Soil 5-10 $\mathrm{cm}$ layer } \\
\hline T1 & $1.15 \mathrm{C}$ & $0.38 \mathrm{~B}$ & $0.019 \mathrm{C}$ & 21.21A \\
\hline $\mathrm{T} 2$ & $3.20 \mathrm{~A}$ & $0.47 \mathrm{~A}$ & $0.025 \mathrm{~B}$ & $18.18 \mathrm{~B}$ \\
\hline T3 & $1.80 \mathrm{~B}$ & $0.37 \mathrm{~B}$ & $0.023 \mathrm{~B}$ & $16.06 \mathrm{C}$ \\
\hline $\mathrm{T} 4$ & $1.95 \mathrm{~B}$ & $0.38 \mathrm{~B}$ & $0.029 A$ & 13.36D \\
\hline T5 & $1.95 \mathrm{~B}$ & $0.42 \mathrm{~B}$ & $0.021 \mathrm{C}$ & 20.49A \\
\hline T6 & $1.70 \mathrm{~B}$ & $0.40 \mathrm{~B}$ & $0.025 \mathrm{~B}$ & $15.79 \mathrm{C}$ \\
\hline $\mathrm{T} 7$ & $1.44 \mathrm{C}$ & $0.32 \mathrm{~B}$ & $0.015 D$ & 21.53A \\
\hline
\end{tabular}




\begin{tabular}{ccccc}
\hline T8 & $1.65 \mathrm{~B}$ & $0.35 \mathrm{~B}$ & $0.024 \mathrm{~B}$ & $\mathbf{1 4 . 2 4 D}$ \\
\hline CV \% & 16.86 & 6.77 & 6.56 & 3.92 \\
\hline T1 & \multicolumn{4}{c}{ Soil $10-20$ cm layer } \\
T2 & $1.00 \mathrm{~B}$ & $0.27 \mathrm{~B}$ & $\mathbf{0 . 0 1 0 C}$ & $\mathbf{2 5 . 8 1 A}$ \\
T3 & $1.00 \mathrm{~B}$ & $\mathbf{0 . 1 4 E}$ & $0.007 \mathrm{D}$ & $19.23 \mathrm{D}$ \\
T4 & $0.90 \mathrm{~B}$ & $0.17 \mathrm{D}$ & $0.008 \mathrm{D}$ & $22.91 \mathrm{~B}$ \\
T5 & $\mathbf{0 . 6 0 C}$ & $\mathbf{0 . 1 2 E}$ & $0.006 \mathrm{D}$ & $20.34 \mathrm{C}$ \\
T6 & $\mathbf{1 . 5 5 A}$ & $0.28 \mathrm{~B}$ & $\mathbf{0 . 0 1 4 A}$ & $21.35 \mathrm{C}$ \\
T7 & $\mathbf{1 . 4 5 A}$ & $\mathbf{0 . 3 1 A}$ & $0.012 \mathrm{~B}$ & $\mathbf{2 6 . 5 8 A}$ \\
T8 & $1.00 \mathrm{~B}$ & $0.18 \mathrm{D}$ & $0.012 \mathrm{~B}$ & $\mathbf{1 5 . 9 3 E}$ \\
CV $\%$ & $\mathbf{1 . 2 0 A}$ & $0.23 \mathrm{C}$ & $\mathbf{0 . 0 1 4 A}$ & $\mathbf{1 6 . 8 8 E}$ \\
\hline
\end{tabular}

Means followed by the same uppercase letter in the columns are not significantly different (comparing treatments, for bulk soil and aggregates) by the Scott-Knott test $(p<0.05)$. CV = coefficient of variation. T1 = rotation with onion, and maize in no-tillage system (NTS); T2 = rotation with soil cover crops (winter), and biennial onion in NTS; T3 = rotation with maize, winter grasses, and onion in NTS; T4 = rotation with summer legume and annual onion in NTS; T5 = rotation with summer grass, winter grasses, and annual onion in NTS; T6 = rotation with summer legume, winter grass, and annual onion in NTS; T7 = rotation with maize and onion in conventional tillage system (CTS); T8 = rotation with intercrops of soil cover crops (summer), and annual onion in NTS.

The highest LOM-C/N in the $0-5 \mathrm{~cm}$ layer was found in $\mathrm{T} 5$ and $\mathrm{T} 7$, and the lowest in T8. In the 5-10 cm layer, T1, T5, and T7 had the highest LOM-C/N, and T4 and T8 had the lowest. In the 10-20 cm layer, T1 and T6 had the highest LOM-C/N, and T7 and T8 had the lowest.

\section{Discussion}

\subsection{POC in the Bulk Soil and Macroaggregates}

The results found for bulk soil and aggregates of the soil surface layer $(0-5 \mathrm{~cm})$ showed that the evaluation of POC is an alternative to differentiate the studied areas, according to the soil managements used. The treatments under NTS have annual additions of plant residues and, combined with a minimum soil turning, they allow the soil cover to remain on the soil surface, which increases POC contents. However, this situation was not found for the treatment under CTS (T7), in which the soil cover is from natural vegetation and maize crop residues, but the soil is turned, thus incorporating these plant residues to deeper layers, resulting in a fast mineralization.

The evaluation of POC in aggregates of the soil surface layer was more efficient to differentiate the treatments than the evaluation of POC in the bulk soil. The POC found in the bulk soil presented no difference among the treatments under NTS; however, the POC in aggregates differentiated the treatments, highlighting the treatment $\mathrm{T} 1$, in which soil cover crops were not used.

In the bulk soil of in the 5-10 cm layer, the combination of leguminous and grass species in $\mathrm{T} 2$ and $\mathrm{T} 6$ resulted in plant residues with an intermediate $\mathrm{C} / \mathrm{N}$, between the original $\mathrm{C} / \mathrm{N}$ of the legumes and grass plants used. The POC fraction had predominance of compounds with high $\mathrm{C}$ content; therefore, residues with high $\mathrm{C} / \mathrm{N}$ tend to remain longer in the soil, increasing 
the soil POC contents (Cotrufo et al., 2019).

The combination of different plant species to generate residues with intermediate $\mathrm{C}$ and $\mathrm{N}$ was also reported by Scherer-Lorenzen et al. (2008) and Duval et al. (2016). These studies showed residues with intermediate $\mathrm{C} / \mathrm{N}(\mathrm{C} / \mathrm{N}=30)$ for combination of soil cover plants (oat + vetch) when compared to treatments with only grass species or legume species.

The lower POC contents found in T1 and T7 may be due to the lower contribution of the natural vegetation to the plant residues when compared to the soil cover plants; despite the natural vegetation is more rustic, they are less efficient to accumulate dry matter (Maia et al., 2015).

The higher POC contents found in the bulk soil of the 10-20 cm layer in the treatments T2, T3, T5, and T8 may be due to the carbon contribution of the grass species roots, which elongate and explore deeper soil layers and present frequent renewal (Dietzel et al., 2017). The lower POC contents found in this layer in T4 and T6 may be due to the residues of the velvet bean, which is a leguminous species and has lower $\mathrm{C} / \mathrm{N}$, which is preferentially mineralized, tending to be fractionated and associated with the MOC fraction.

Some studies on soils managed under NTS and minimum tillage report increases in COT contents with a consequent increase in POC and MOC fractions, in the $0-30 \mathrm{~cm}$ layer, when compared to those managed under CTS; this is related to a lower soil turning and to a greater quantity and frequent addition of plant residues through rhizodeposition of soil cover plants (Cates et al., 2016; Lima et al., 2016; Melo et al., 2016; Comin et al., 2018; Abdala et al., 2020).

The POC contents in aggregates of the treatments varied according to the soil layer; however, the use of grass species increased this carbon fraction mainly in the subsurface layers (5-10 and 10-20 cm). The treatment T5, for example, consisted of a sequence of grass species in rotation with onion crops that resulted in higher POC contents than the other treatments, except for the 10-20 cm soil layer, when compared to T8 and T7, which were similar to T5. Therefore, the permanent contribution of organic residues in the NTS and the polysaccharides exuded by their root system contribute to soil aggregation and carbon stabilization in aggregates (Rauber et al., 2017; Loss et al., 2019).

The higher POC contents found in aggregates of the 10-20 cm layer in the treatment T7 was due to the incorporation of plant residues to the soil by plowing and harrowing, which also explains why T7 had the lowest POC contents in aggregates of the $0-5 \mathrm{~cm}$ soil layer. POC contents in T8 and T5 were similar for the layer 10-20 cm because of the intercrop of soil cover crops, which resulted in higher DMG and POC contents in macroaggregates (Giumbelli et al., 2020), creating an environment that provided higher protection for POC.

The POC contents in bulk soil and aggregates showed differences for these compartments in all treatments; the highest contents were always found in the bulk soil. This may be due to the constant maintenance of plant residues on the soil surface and absence of soil turning, which enrich the environment with particles with sizes $>53 \mu \mathrm{m}$ associated with the POC fraction. Similar results were found by Ferreira et al. (2018), who evaluated POC contents in bulk soil 
and macroaggregates under different management systems and soil cover plants.

\subsection{MOC in the Bulk Soil and Macroaggregates}

The higher MOC contents in the bulk soil of the $0-5 \mathrm{~cm}$ layer found in the treatments $\mathrm{T} 4$ and T5 were because of the successive crops without soil turning and the use of soil cover plants. More than $80 \%$ of COT is composed of MOC; thus, the addition of plant materials for the maintenance and increase of COT contents increases the compartments of MOC in the soil (Bayer et al. 2004; Conceição et al., 2013). The higher MOC contents in T4 and T5 corroborates the higher COT contents in these treatments (Giumbelli et al., 2020).

The 5-10 and 10-20 cm layers of treatments with velvet bean, alone (T4) or intercropped with grass species (T6 and T8), presented higher MOC contents in the bulk soil. This indicates that the rhizodeposition of nitrogen-rich materials that facilitates their decomposition by microorganisms, forming residues that can be associated with silt and clay particles $(<0.53 \mu \mathrm{m})$. Canarini et al. (2018) found positive correlation between legume biomasses and MOC contents $(\mathrm{R} 2=0.38, \mathrm{p}<0.001)$, which corroborates the results found in the present work.

The SOM labile fraction presents high decomposition rate and short permanence period in the soil; its main function is the supplying of nutrients to plants by mineralization, and energy and $\mathrm{C}$ to soil microorganisms. Some studies report negative correlation between MOC and POC, indicating that a higher MOC accumulation is resulted from the decomposition of POC (Silva \& Mendonça, 2007; Conceição et al., 2013; Lima et al., 2016; Ferreira et al., 2018).

Conceição et al. (2005) evaluated soils (Typic Hapludult) under CTS, minimum tillage, and NTS using seven treatments with grass species and legumes, with and without use of soil nitrogen fertilization, and found that the treatments with legumes add higher quantities of POC and MOC to the $0-20 \mathrm{~cm}$ soil layer.

The lower MOC contents in the bulk soil of all soil layers in T1 were also due to the absence of soil turning, requiring the contribution of carbon-rich materials (use of soil cover plants) to form and maintain this more recalcitrant carbon fraction in the soil.

Contrastingly, the higher MOC contents found in aggregates of the 0-5 and 10-20 cm layers in $\mathrm{T} 1$ denote that the conversion of POC into MOC in aggregates was more efficient than that occurring in the bulk soil, which may be due to a physical protection provided by the soil aggregates. The POC is the point of nucleation for soil particles, increases the microbial activity and, consequently, forms microaggregates (Kumar et al., 2013). The joint of microaggregates forms macroaggregates and, thus, more recalcitrant carbon will be protected, i.e., the MOC contents will be increased (Xu et al., 2019).

The higher MOC contents in aggregates in T2, T4, T5, and T6 $(0-5 \mathrm{~cm}), \mathrm{T} 5(5-10 \mathrm{~cm})$, and T8 $(10-20 \mathrm{~cm}$ ) were due to the preservation of the soil structure in the NTS (Giumbelli et al., 2020). This favors the formation of stable aggregates, the release of exudates rich in polysaccharides and cementitious agents by the soil cover plants, and the permanence of plant residues that protect the aggregates and decrease the soil surface temperature, leading to the cycling of carbon. These factors show the better conversion of POC into MOC of soil 
aggregates.

The comparison of the POC and MOC contents in bulk soil and aggregates within each treatment showed, in general, higher POC contents in the bulk soil. The MOC contents showed higher variations, presenting sometimes higher contents in the bulk soil and sometimes higher contents in aggregates. The results showed higher MOC contents in aggregates in T1, and in the bulk soil in T7, in all layers evaluated. These results corroborate the higher aggregation indexes of T1 when compared to T7 (Giumbelli et al. 2020). Larger and more stable aggregates provided a more favorable environment for the formation and maintenance of MOC contents in T1 (NTS) when compared to T7 (CTS).

The predominance of higher proportions of carbon in MOC form was found in the bulk soil and aggregates, in all layers evaluated. Studies on SOM granulometric fractions showed higher proportions of non-labile carbon fractions when comparing the MOC with labile fractions (POC) (Lima et al., 2016). However, the aggregates in the 10-20 cm layer in the treatment $\mathrm{T} 7$ presented the lowest MOC contents. These results reinforce the negative effect of CTS regarding the breaking of aggregates, with consequent loss of carbon, affecting less-stable aggregates, as reported by Giumbelli et al. (2020).

The use of NTS contributed to increases in MOC contents because changes in MOC contents and stocks are followed by humification of labile organic matter (POC) and its higher interaction with mineralogical components - silt and clay fractions (Lima et al, 2016). Loss et al. (2009) found higher MOC contents in an NTS for vegetables with soil organic fertilization when compared to a CTS; these differences were attributed to the constant use of soil organic fertilization, and to the history and time of use of each area under NTS when compared to the CTS.

\subsection{PON in the Bulk Soil and Macroaggregates}

The higher PON contents found in the treatments under NTS with soil cover plants, when compared to T7, was because of the preservation of the soil structure, which protected the SOM and, consequently, decreased the microbial decomposition rate. This shows that PON is also sensitive to soil managements for crops; a maize crop under NTS, with velvet bean (Mucuna aterrima) as soil cover plants, showed gains of $34.9 \%$ in PON over a crop under CTS (Souza Nunes et al., 2011).

The higher PON contents in the bulk soil of the $0-5 \mathrm{~cm}$ layer in T2, T4, T6, and T8 were mainly due to the decomposition of vetch and oilseed radish (T2) and velvet bean (T4, T6, T8) plants, which provided nitrogen-rich residues. Contrastingly, the higher PON contents found in the bulk soil of $0-5 \mathrm{~cm}$ layer in T3 and T5 may be due to the immobilization of $\mathrm{N}$ by the grass species used, which contain more $\mathrm{C}$ in their tissues, decreasing the decomposition rate of plant residues and increasing PON contents due to their slower mineralization (Veras et al., 2016; Fu et al., 2019).

Increases in nitrogen stocks in the particulate fraction favor the availability of this nutrient to plants because of the short time of influence of this fraction and its concentration in the soil surface layer, favoring the absorption of $\mathrm{N}$ by roots of plants (Conceição et al., 2005). 


\section{Macrothink Institute ${ }^{\mathrm{TM}}$}

The higher PON contents found in the bulk soil of the 5-10 and 10-20 cm layers in T5 were because of the presence of grass species (oat, rye, and millet) in the summer and in the winter. These plants efficiently absorb inorganic nitrogen from the soil solution, such as $\mathrm{NO}_{3}-$, converting it into organic $\mathrm{N}$, and releasing it to the soil when the plants tissues of the soil cover crops are decomposed (Beltrán et al., 2018).

In addition to the immobilization of $\mathrm{N}$ by grass species in $\mathrm{T} 8$, the diversity of plant species (grass and legumes species) and the high contribution of LOM to the 10-20 cm layer (Table 7) can be related to the high PON contents in this layer, since the LOM was from velvet bean plant residues, which accumulate nitrogen in deep soil layers.

However, the higher PON contents found in the bulk soil of the 10-20 cm layer in T7 may be due to the material buried through the soil turning, together with the nitrogen from the soil fertilization, natural vegetation, and maize crop residues from soil surface layers to deeper layers. The lower PON contents found in the bulk soil of the $0-5 \mathrm{~cm}$ layer in T7 confirm this explanation.

The higher PON contents found in aggregates of the $0-5$ and $5-10 \mathrm{~cm}$ soil layers in T6 are related to the combination of velvet bean and rye as soil cover plants, forming plant residues with intermediate $\mathrm{C} / \mathrm{N}$ (> 20 and $<30$ ), which provided a favorable environment for a slow decomposition and made possible the protection of this material in the interior of aggregates. This favorable environment was not found in $\mathrm{T} 7$ because of the absence of soil cover plants and frequent soil turning, which explains the lower PON contents found in aggregates of the $0-5$ and $5-10 \mathrm{~cm}$ soil layer in this treatment.

The PON contents in the 5-10 cm layer in T1 and T7 were similar; however, T1 presented higher POC and PON contents in the bulk soil and aggregates, and higher MOC and MON contents in the bulk soil of the $0-5 \mathrm{~cm}$ layer than T7. This shows that the management practices used in NTS provide higher carbon and nitrogen contents on the soil surface than those in CTS. NTS also preserves aggregates, which improves water infiltration rate, total porosity, and nutrient retention capacity of the soil (Blanco \& Lal, 2004).

Considering the treatments under NTS, the lowest PON contents found in aggregates of the treatment $\mathrm{T} 3(0-5 \mathrm{~cm}$ layer) and T3 and T1 $(5-10 \mathrm{~cm}$ layer $)$ were due to the exclusive use of grass species, which increase more efficiently the soil aggregation, but are less efficient in biological nitrogen fixation than leguminous species.

The PON in the bulk soil and aggregates within the treatments showed an opposite pattern to POC, i.e., the higher PON contents were found in aggregates of all soil layers evaluated. This denotes the importance of preserving the soil structure, which enables the formation of aggregates that protect this nitrogen fraction and, consequently, its maintenance for the subsequent crops.

Organic substrates are physically protected inside soil aggregates, decreasing the accessibility of microorganisms and, consequently, the soil microbial activity, and protecting the $\mathrm{C}$ and $\mathrm{N}$ from decomposition, accumulating more $\mathrm{C}$ and $\mathrm{N}$ in aggregates than in the bulk soil (Zhong et al., 2017). 
The PON contents presented no differences between bulk soil and aggregates for the CTS (T7). This may be due to the soil turning and breaking of aggregates, which homogenize the PON contents in bulk soil and aggregates. This reinforces the importance of the NTS to preserve the soil structure and the subsequent accumulation of PON in the interior of aggregates.

\subsection{MON in Bulk Soil and Macroaggregates}

The higher MON contents found in the bulk soil $(0-5 \mathrm{~cm})$ and aggregates $(10-20 \mathrm{~cm})$ in T4, $\mathrm{T} 6$, and $\mathrm{T} 8$, and in the bulk soil in T8 $(5-10 \mathrm{~cm})$ and aggregates in T4 $(0-5$ and $5-10 \mathrm{~cm})$ were due to the nitrogen provided by the decomposition of soil cover plants, especially, velvet bean plants which associate with rhizobacteria and fix nitrogen bacteria that form residues with low $\mathrm{C} / \mathrm{N}(<20)$. This facilitates that microorganisms transform this plant material into smaller particles that can bound to the surface of minerals of the clay fraction (Giannetta et al., 2019).

The higher MON contents found in the bulk soil of the 0-5 and 5-10 cm layers in T5 may be related to the successive crops with soil cover plants from the Poaceae family, which results in plant residues with nitrogen-rich tissues, and increases SOM contents and supply of particulate nitrogen over time (Personeni et al., 2005; Fu et al., 2019).

The lower MON contents found in aggregates of the $0-5$ and 10-20 cm layers in T1 and T7, and of the 5-10 cm layer in T1 may be due to the contribution of this nutrient to the two treatments only by soil mineral fertilization and residues of natural vegetation. In addition, T7 also presented breaking of the soil structure, which made the previously protected MON in aggregates able to be consumed by microorganisms or lost in the environment (Santos et al., 2018a).

The higher MON contents found in aggregates of all soil layers evaluated in T4 indicate a trend of velvet bean residues to mineralize faster than grass species, facilitating the association of silt and clay fractions in the soil, protecting the MON in the interior of aggregates (Lavallee et al., 2019).

The same pattern was found in T6 and T8, but only in the 5-10 cm soil layer; in this case, the velvet bean was intercropped with grass species, making the decomposition of residues slower in the soil surface layer, decreasing MON contents in this soil layer $(0-5 \mathrm{~cm})$. The other treatments showed a trend to accumulate MON in aggregates and bulk soil, but T7 presented lower and homogeneous MON contents probably due the soil turning and breaking of aggregates, as found for PON.

\subsection{Light Organic Matter (LOM), LOM-C, and LOM-N Contents}

The higher LOM contents found in the 0-5 and 5-10 cm layers in the treatment T2 may be due to the use of vetch and combination of oilseed radish and rye, which added $9.73 \mathrm{Mg} \mathrm{ha}^{-1}$ of dry matter to the soil in 2016 (Table 3). The aerial part of oilseed radish plants can add 1,965 to $3,361 \mathrm{~kg} \mathrm{ha}^{-1}$ of dry matter to the soil, and their roots can add 1,532 to $3,748 \mathrm{~kg} \mathrm{ha}^{-1}$ of dry matter to deeper soil layers (Wang \& Weil, 2018). 
However, dry matter with high proportion of $\mathrm{N}$ is rapidly decomposed by the soil microbiota (Jahanzad et al., 2016). Therefore, the combination of oilseed radish with rye, combined with maize plant residues, assisted in balancing the $\mathrm{C} / \mathrm{N}$ of the residues, mainly in the $5-10 \mathrm{~cm}$ layer $(\mathrm{C} / \mathrm{N}=18.18)$, enabling the LOM formed in the treatment $\mathrm{T} 2$ to remain longer in the soil (Table 7) (Morton \& Abendroth, 2017).

The combination of plants of different families was efficient to accumulate LOM in the 10-20 cm layer in the treatment T8, in which the sunflower root system had more effect in the first $10 \mathrm{~cm}$ of soil, and the velvet bean and millet tended to develop roots below this layer (Scapinelli et al., 2016).

The higher LOM contents found in the 10-20 cm layer in T5 and T6 may be due to the use of rye as soil cover plants. This plant has high capacity to generate dry matter (DM) (17 to 35 $\mathrm{Mg} \mathrm{ha}^{-1}$ ) with high $\mathrm{C} / \mathrm{N}$, which improved the quantity of DM in the soil surface layer of the treatment T5 (Table 3) (Chaves et al., 2018). In addition, the rye root system is regularly renewed and tends to deposit organic material in deep soil layers (Loss et al., 2015).

The lower LOM contents found in the $0-5$ and 5-10 cm layers in T7 may be due to the absence of soil cover plants, resulting in a lower contribution of plants to the LOM, which, combined with the soil turning (CTS), results in plant residues with lower size and increases their decomposition rate (Loss et al., 2010). In addition, T7 had lower DM contents in soil surface layer (Table 3).

T1 presented higher LOM contents in the soil surface layer than T7, confirming the DM data- $\mathrm{T} 1$ produced 1.0 $\mathrm{Mg} \mathrm{ha}^{-1}$ more DM than $\mathrm{T} 7$ (Table 3). These differences show that, despite the use of soil cover plants in T1, the soil management in NTS kept the residues of natural vegetation on the soil and improved the contribution of LOM when compared to T7 (CTS). T1 and T7 presented no differences in the 5-10 and 10-20 cm layers; this is related to the soil turning in $\mathrm{T} 7$, which incorporated the plant residues from the $0-5 \mathrm{~cm}$ to deeper layers, as reported by Loss et al. (2010) and Pereira et al. (2010).

The lower LOM contents found in the 10-20 cm layer in T4 may be due to the use of velvet bean alone, which generated residues poor in carbon and rich in nitrogen, which were easily decomposed by microorganisms. These higher $\mathrm{N}$ contents in the plant residues are confirmed by the LOM-C/N in all soil layers evaluated in T4, especially in the soil surface layer (11.17) (Table 7).

The higher LOM-C contents found in the $0-5 \mathrm{~cm}$ layer in T8 are related to the use of soil cover plants of different families and the consecutive crops under NTS. This corroborates the DM contents (11.0 $\mathrm{Mg} \mathrm{ha}^{-1}$ ) found in the soil surface layer (Table 3). Studies show that millet intercropped with velvet bean and other legumes can produce, in general, $10 \mathrm{Mg} \mathrm{ha}^{-1}$ of DM; moreover, sunflower plants can provide 6.5 to $11.1 \mathrm{Mg} \mathrm{ha}^{-1}$ of DM to the soil surface when used alone as soil cover plants (Herrada et al., 2017; Büchi et al., 2020). This resulted in higher accumulation and preservation of plant residues on the soil surface, despite of their low $\mathrm{C} / \mathrm{N}$ (12.47), when compared to the LOM of the other treatments (Table 7).

Considering the LOM-C and LOM-N contents, T1 had higher C (0-5 and 10-20 cm) and N 
$(0-5$ and $5-10 \mathrm{~cm})$ contents, and more DM on the soil surface than T7 (Table 3$)$. These treatments had the same crop rotation (maize-onion), without the use of soil cover plants. Maize adds carbon through plant residues, mainly roots, which add 3-fold more carbon than the shoot (Müller et al. 2016). Thus, the differences between T1 and T7 are due to the tillage system used, i.e., the NTS in T1 favored the soil cover. This improves the DM production and the LOM, LOM-C, and LOM-N contents when compared to T7, in which the use of CTS incorporated the plant residues and accelerated their decomposition. This was also found by Assunção et al. (2019), who evaluated the effect of CTS and NTS on SOM fractions of tropical soils and found higher LOM contents when using NTS.

The higher LOM-N contents found in T4 $(0-5$ and 5-10 cm) and T8 $(0-5$ and 10-20 cm) were due to the use of leguminous species, which generated nitrogen-rich plant residues. This was also found in T2 and T6, which had leguminous species as soil cover crops and presented higher LOM-N contents in the soil surface layer when compared to the treatments using only grass species (T1, T3, and T5).

Moreover, the higher LOM-C and LOM-N contents found in the $0-5 \mathrm{~cm}$ layer in T8 indicated that the combination of soil cover plants from different families increases DM yield and, consequently, the contents of these nutrients in the soil (Michelon et al., 2019). In addition, the resulting low $\mathrm{C} / \mathrm{N}$ indicates that these and other nutrients can faster be available to plants (Redin et al., 2014).

\section{Conclusions}

The frequent soil turning caused by the conventional tillage system (CTS) in the treatment T7 resulted in lower particulate organic $\mathrm{C}$ and $\mathrm{N}$ (POC and PON) contents in soil macroaggregates and bulk soil (0-5 cm layer) when compared to treatments under no tillage system (NTS). The use of CTS (T7) resulted in lower light organic matter (LOM), LOM-C, and LOM-N contents in the soil surface layer when compared to the other treatments. This denotes that the soil management in the NTS assists in the maintenance of residues of soil cover crops and natural vegetation on the soil and improves the LOM and granulometric fractions of the soil organic matter.

The absence of soil cover plants in T1 resulted in lower MOC contents in bulk soil, and lower MON contents in aggregates, in all evaluated layers, when compared to the other treatments under NTS. The higher diversity and combinations of plant species in T2, T3, T4, T5, T6, and T8 resulted in higher POC and MON contents in aggregates and MOC and PON contents in bulk soil, in the soil surface layer, when compared to T1 and T7.

The crop rotation with velvet bean followed by rye + oilseed radish as soil cover plants (T2) was a better option to increase LOM and POC contents (in aggregates) in the soil surface layer when compared to the other treatments. The treatments with legumes were more efficient to increase $\mathrm{N}$ contents $(0-10 \mathrm{~cm}$ layer) - especially PON in $\mathrm{T} 6$, which included a rotation with summer legume-winter grass species; and MON in T4, which included a rotation with onion crops with summer legume, both in aggregates - and LOM-N contents in T4. 


\section{Macrothink Institute ${ }^{\mathrm{TM}}$}

The POC $(0-5 \mathrm{~cm})$, PON, and MON $(0-10 \mathrm{~cm})$ contents in soil aggregates showed more significant differences between treatments than the contents in the bulk soil. The onion crops under NTS including the use of rotation with soil cover plants were more efficient to improve the evaluated soil attributes than the crops under CTS.

\section{Conflict of interest}

The authors declare that they have no known competing financial interests or personal relationships that could have appeared to influence the work reported in this paper.

\section{Acknowledgments}

The authors express their thanks to the National Council for Scientific and Technological Development - CNPq (Process No 302603 / 2015-8; 403949 / 2016-5 AND 306118 / 2018-1) and the Experimental Station of Ituporanga, SC, Brazil, for the availability of the experimental area. This study was financed in part by the Coordination for the Improvement of Level Personnel Superior, - Brazil (CAPES) - Finance Code 001.

\section{References}

Abdalla Fayad, J., Comin, J. J., Mafra, A., Kurtz, C., Fayad, S., Rodrigues Madeira, N., ... Ferreira, G. W. (2020). Management of vegetable Conservation Agriculture systems. Burleigh Dodds Series in Agricultural Science. 01ed.: Burleigh Dodds Science Publishing, 1, 279-326. https://doi.org/10.19103/AS.2019.0048.08

Alvares, C. A., Stape, J. L., Sentelhas, P. C., Gongalves, J. L. M., \& Sparovek, G. (2013). Koppen's climate classification map for Brazil. Meteorologische Zeitschrift, 22, 711-728. https://doi.org/10.1127/0941-2948/2013/0507

Anderson, J. M., \& Ingram, J. S. I. (1994). Tropical soil biology and fertility: a handbook of methods. Soil Science, 157(4), 265. https://doi.org/10.1097/00010694-199404000-00012

Assunção, S. A., Pereira, M. G., Rosset, J. S., Berbara, R. L. L., García, A. C. (2019). Carbon input and the structural quality of soil organic matter as a function of agricultural management in a tropical climate region of Brazil. Science of the Total Environment, 658, 901-911. https://doi.org/10.1016/j.scitotenv.2018.12.271

Bartlett, M. S. (1937). Properties of sufficiency and statistical tests. Proceedings of the Royal Society of London. Series A, Mathematical and Physical Sciences 160(901), 268-282. https://doi.org/10.1098/rspa.1937.0109

Bayer, C., Martin-Neto, L., Mielniczuk, J., \& Pavinato, A. (2004). Armazenamento de carbono em frações lábeis da matéria orgânica de um Latossolo Vermelho sob plantio direto. Pesquisa Agropecuária Brasileira, 39(7), 677-683.

https://doi.org/10.1590/S0100-204X2004000700009

Beltrán, M. J., Sainz-Rozas, H., Galantini, J. A., Romaniuk, R. I., \& Barbieri, P. (2018). Cover crops in the Southeastern region of Buenos Aires, Argentina: effects on organic matter physical fractions and nutrient availability. Environmental Earth Sciences, 77(12), 428. https://doi.org/10.1007/s12665-018-7606-0 
Blanco-Canqui, H., \& Lal, R. (2004). Mechanisms of carbon sequestration in soil aggregates. Critical reviews in plant sciences, 23(6), 481-504.

https://doi.org/10.1080/07352680490886842

Büchi, L., Wendling, M., Amossé, C., Jeangros, B., \& Charles, R. (2020). Cover crops to secure weed control strategies in a maize crop with reduced tillage. Field Crops Research, 247, 107583. https://doi.org/10.1016/j.fcr.2019.107583

Cambardella, C. A., \& Elliott, E. T. (1994). Carbon and nitrogen dynamics of soil organic matter fractions from cultivated grassland soils. Soil Science Society of America Journal, 58(1), 123-130. https://doi.org/10.2136/sssaj1994.03615995005800010017x

Canarini, A., Mariotte, P., Ingram, L., Merchant, A., \& Dijkstra, F. A. (2018). Mineral-associated soil carbon is resistant to drought but sensitive to legumes and microbial biomass in an Australian grassland. Ecosystems, 21(2), 349-359. https://doi.org/10.1007/s10021-017-0152-X

Cates, A. M., Ruark, M. D., Hedtcke, J. L., \& Posner, J. L. (2016). Long-term tillage, rotation and perennialization effects on particulate and aggregate soil organic matter. Soil and Tillage Research, 155, 371-380. https://doi.org/10.1016/j.still.2015.09.008

Chaves, G. G., Cargnelutti Filho, A., Carini, F., Andiara Kleinpaul, J., Neu, M., Mario, I., \& Procedi, A. (2018). Tamanho de parcela e número de repetições para avaliação de caracteres vegetativos em centeio. Brazilian Journal of Agricultural Sciences, 13(3). https://doi.org/10.5039/agraria.v13i3a5563

Chen, J., Xiao, W., Zheng, C., \& Zhu, B. (2020). Nitrogen addition has contrasting effects on particulate and mineral-associated soil organic carbon in a subtropical forest. Soil Biology and Biochemistry, 107708. https://doi.org/10.1016/j.soilbio.2020.107708

Comin, J. J., Ferreira, L. B., Dos Santos, L. H., Paula Koucher, L., Machado, L. N., Dos Santos, J., \& Loss, A. (2018). Carbon and nitrogen contents and aggregation index of soil cultivated with onion for seven years using crop successions and rotations. Soil and Tillage Research, 184, 195-202. https://doi.org/10.1016/j.still.2018.08.002

Conceição, P. C., Amado, T. J. C., Mielniczuk, J., \& Spagnollo, E. (2005). Qualidade do solo em sistemas de manejo avaliada pela dinâmica da matéria orgânica e atributos relacionados. Revista brasileira de ciencia do solo. Campinas. 29, 777-788.

https://doi.org/10.1590/S0100-06832005000500013

Conceição, P.C., Dieckow, J., \& Bayer, C. (2013). Combined role of no tillage and cropping systems in soil carbon stocks and stabilization. Soil and Tillage Research, 129, 40-47. https://doi.org/10.1016/j.still.2013.01.006

Cotrufo, M. F., Ranalli, M. G., Haddix, M. L., Six, J., \& Lugato, E. (2019). Soil carbon storage informed by particulate and mineral-associated organic matter. Nature Geoscience, 12(12), 989-994. https://doi.org/10.1038/s41561-019-0484-6

Dietzel, R., Liebman, M., \& Archontoulis, S. (2017). A deeper look at the relationship 
between root carbon pools and the vertical distribution of the soil carbon pool. Soil, 3(3), 139. https://doi.org/10.5194/soil-3-139-2017

Duval, M. E., Galantini, J. A., Capurro, J. E., \& Martinez, J. M. (2016). Winter cover crops in soybean monoculture: Effects on soil organic carbon and its fractions. Soil and Tillage Research, 161, 95-105. https://doi.org/10.1016/j.still.2016.04.006

Embrapa - Empresa Brasileirade Pesquisa Agropecuária. Centro Nacional de Pesquisa de Solos. Manual de métodos de análise de solo. 2. ed. Rio de Janeiro, 1997. 212p. (Embrapa-CNPS. Documentos, 1).

Fernández, R., Quiroga, A., Zorati, C., \& Noellemeyer, E. (2010). Carbon contents and respiration rates of aggregate size fractions under no-till and conventional tillage. Soil Tillage Research, 109, 103-109. https://doi.org/10.1016/j.still.2010.05.002

Ferreira, L. B., Loss, A., Giumbelli, L. D., Ventura, B. S., Souza, M., Mafra, Á. L., ... Brunetto, G. (2018). Organic carbon and nitrogen contents and their fractions in soils with onion crops in different management systems. Soil Research, 56, 846-855. https://doi.org/10.1071/SR18167

Food and Agricultural Organization-FAO, (2020). Crops.

http://www.fao.org/faostat/en/\#data/QC (accessed April 6, 2020).

Fu, X., Wang, J., Sainju, U. M., \& Liu, W. (2018). Soil nitrogen fractions under long-term crop rotations in the Loess Plateau of China. Soil and Tillage Research, 186, 42-51. https://doi.org/10.1016/j.still.2018.10.004

Giannetta, B., Plaza, C., Zaccone, C., Vischetti, C., \& Rovira, P. (2019). Ecosystem type effects on the stabilization of organic matter in soils: Combining size fractionation with sequential chemical extractions. Geoderma, 353, 423-434.

https://doi.org/10.1016/j.geoderma.2019.07.009

Giumbelli, L. D., Loss, A., Ventura, B. S., Santos Junior, E., Almeida, J., Piccolo, M. C., ... Comin, J. J. (2020). Aggregation index, carbon, nitrogen, and natural abundance of ${ }^{13} \mathrm{C}$ and ${ }^{15} \mathrm{~N}$ in soil aggregates and bulk soil cultivated with onion under crop successions and rotations. Soil Research, 58, 622-635. https://doi.org/10.1071/SR19346

Herrada, M. R., Mozena Leandro, W., \& Ferreira, E. P. D. B. (2017). Leguminosas isoladas e consorciadas com milheto em diferentes sistemas de manejo do solo no feijão orgânico. Terra Latinoamericana, 35(4), 293-299. https://doi.org/10.28940/terra.v35i4.165

Instituto Brasileiro de Geografia e Estatistica - IBGE, (2020).

https://cidades.ibge.gov.br/brasil/sc/pesquisa/14/10251 (accessed April 6, 2020).

Jahanzad, E., Barker, A. V., Hashemi, M., Eaton, T., Sadeghpour, A., \& Weis, S. A. (2016). Nitrogen Release Dynamics and Decomposition of Buried and Surface Cover Crop Residues. Agronomy Journal, 108(4), 1735. https://doi.org/10.2134/agronj2016.01.0001

Kumar, R., Rawat, K. S., Singh, J., Singh, A., \& Rai, A. (2013). Soil aggregation dynamics and carbon sequestration. Journal of Applied and Natural Science, 5, 250-267. 
https://doi.org/10.31018/jans.v5i1.314

Lange, M., Eisenhauer, N., Sierra, C. A., Bessler, H., Engels, C., Griffiths, R. I., \& Steinbeiss, S. (2015). Plant diversity increases soil microbial activity and soil carbon storage. Nat Commun, 6. https://doi.org/10.1038/ncomms 7707

Lavallee, J. M., Soong, J. L., \& Cotrufo, M. F. (2019). Conceptualizing soil organic matter into particulate and mineral associated forms to address global change in the 21 st century. Global change biology, 26(1), 261-273. https://doi.org/10.1111/gcb.14859

Lilliefors, H. W. (1967). On the Kolmogorov-Smirnov test for normality with mean and variance unknown. Journal of the American Statistical Association 62(318), 399-402. https://doi.org/10.1080/01621459.1967.10482916

Lima, C. E. P., Fontenelle, M. R., Madeira, N. R., da Silva, J., Guedes, Í. M. R., Silva, L. R. B., \& Soares, D. C. (2016). Compartimentos de carbono orgânico em Latossolo cultivado com hortaliças sob diferentes manejos. Pesquisa Agropecuária Brasileira, 51(4), 378-387. https://doi.org/10.1590/S0100-204X2016000400011

Loss, A., Costa, E. M., Pereira, M. G., \& Beutler, S. J. (2014). Agregação, matéria orgânica leve e carbono mineralizável em agregados do solo. Revista de la Facultad de Agronomía, La Plata, 113(1), 1-8.

Loss, A., de Lima Moraes, A. G., Pereira, M. G., Da Silva, E. M. R., \& Dos Anjos, L. H. C. (2010). Carbono, matéria orgânica leve e frações oxidáveis do carbono orgânico sob diferentes sistemas de produção orgânica. Comunicata Scientiae, 1(1), 57.

Loss, A., Gonzatto, R., Cesco, S., Mimmo, T., PII, Y., Ventura, B. S., ... Brunetto, G. (2019). Rizosfera e as Reações que Ocorrem no seu Entorno. In: Jamil Abdalla Fayad, Valdemar Arl, Jucinei José Comin, Álvaro Luiz Mafra, Darlan Rodrigo Marchesi. (Org.). Sistema de plantio direto de hortaliças: método de transição para um novo modo de produção. 01ed.São Paulo: Expressão Popular, 01, 175-212.

Loss, A., Lourenzi, C. R., Mergen Junior, C. A., Santos Junior, E., Benedet, L., Pereira, M. G., ... Comin, J. J. (2017b). Carbon, nitrogen and natural abundance of ${ }^{13} \mathrm{C}$ and ${ }^{15} \mathrm{~N}$ in biogenic and physicogenic aggregates in a soil with 10 years of pig manure application. Soil \& Tillage Research, 166, 52-58, https://doi.org/10.1016/j.still.2016.10.007

Loss, A., Schmitz, D., Santos Junior, E., Kurtz, C., da Veiga, M., \& Comin, J. J. (2017a). Atributos físicos do solo sob sistemas de plantio direto e preparo convencional em cultivo de cebola. Revista Colombiana de Ciencias Horticolas, 11, 105-113.

https://doi.org/10.17584/rcch.2017v11i1.6144

Loss, A., Basso, A., Oliveira, B. S., Koucher, L. P., Oliveira, R. A., Kurtz, C., ... Comin, J. J. (2015). Total organic carbon and soil aggregation in an onion agroecological and conventional no-tillage system. Revista Brasileira de Ciência do Solo, 39(4), 1212-1224. https://doi.org/10.1590/01000683rbcs20140718

Loss, A., Pereira, M. G., Schultz, N., Anjos, L. H. C., \& Silva, E. M. R. (2009). Carbono e 
frações granulométricas da matéria orgânica do solo sob sistemas de produção. Ciência Rural, 39, 1067-1072, https://doi.org/10.1590/S0103-84782009005000036

Maia, S. M. F., de Oliveira, T. S., \& Oliveira, F. N. S. (2015). Plantas espontâneas na cobertura do solo e acúmulo de nutrientes em áreas cultivadas com cajueiro. Ceres, 51(293).

Melo, G. B., Pereira, M. G., Perin, A., Guareschi, R. F., \& Soares, P. F. C. (2016). Estoques e frações da matéria orgânica do solo sob os sistemas plantio direto e convencional de repolho. Pesquisa Agropecuária Brasileira, 51(9), 1511-1519.

https://doi.org/10.1590/s0100-204x2016000900050

Menezes Junior, F. O. G. et al. (Coord.). (2013). Onion production system: Santa Catarina. 4. ed. rev. Florianópolis: EPAGRI. 106 p. (Sistemas de produção, no 46).

Michelon, C. J., Junges, E., Casali, C. A., Pellegrini, J. B. R., Neto, L. R., de Oliveira, Z. B., $\&$ de Oliveira, M. B. (2019). Atributos do solo e produtividade do milho cultivado em sucessão a plantas de cobertura de inverno. Revista de Ciências Agroveterinárias, 18(2), 230-239. https://doi.org/10.5965/223811711812019230

Morton, L. W., \& Abendroth, L. J. (2017). Crops, climate, culture, and change. Journal of Soil and Water Conservation, 72(3), 47A-52A. https://doi.org/10.2489/jswc.72.3.47A

Müller, K., Kramer, S., Haslwimmer, H., Marhan, S., Scheunemann, N., Butenschön, O, \& Kandeler, E. (2016). Carbon transfer from maize roots and litter into bacteria and fungi depends on soil depth and time. Soil Biology and Biochemistry, 93, 79-89.

https://doi.org/10.1016/j.soilbio.2015.10.015

Pereira, M. G., Loss, A., Beutler, S. J., \& Torres, J. L. R. (2010). Carbono, matéria orgânica leve e fósforo remanescente em diferentes sistemas de manejo do solo. Pesquisa agropecuaria brasileira, 45(5), 508-514.

https://doi.org/10.1590/S0100-204X2010000500010

Personeni, E., Lüscher, A., \& Loiseau, P. (2004). Rhizosphere activity, grass species and N availability effects on the soil C and N cycles. Soil Biology and Biochemistry, 37(5), 819-827. https://doi.org/10.1016/j.soilbio.2004.08.012

Rauber, L. P., Andrade, A. P., \& Mafra, Á. L. (2017). Soil organic carbon stocks in granulometric fractions under use and management systems with swine and poultry manure. Brazilian Journal of Agriculture-Revista de Agricultura, 92(2), 101-114. https://doi.org/10.37856/bja.v92i2.2648

Redin, M., Recous, S., Aita, C., Dietrich, G., Skolaude, A. C., Ludke, W. H., \& Giacomini, S. J. (2014). How the chemical composition and heterogeneity of crop residue mixtures decomposing at the soil surface affects $\mathrm{C}$ and $\mathrm{N}$ mineralization. Soil biology and biochemistry, 78, 65-75. https://doi.org/10.1016/j.soilbio.2014.07.014

Santos, L. H., Loss, A., Canton, L., Santos Junior, E., Kurtz, C., Brunetto, G., \& Comin, J. J. (2018b). Carbon of humic substances in soil aggregates cultivated with onion under no-till and conventional tillage systems. Idesia (Arica), 36, 15-52. 
Santos, L. H., Loss, A., Canton, L., Souza, M., Ferreira, G. W., Kurtz, C., \& Comin, J. J. (2018a). Carbon and nitrogen content in granulometric fractions of organic matter in soil aggregates under no-tillage and conventional tillage planting systems for onions. Idesia, $36(4), 2$.

Santos, L. H., Loss, A., Canton, L., Ventura, B. S., Ferreira, G. W., Kurtz, C., .. Comin, J. J. (2017). Chemical Properties in Macroaggregates of a Humic Dystrudept Cultivated with Onion under No-Till and Conventional Tillage Systems. Revista Brasileira de Ciencia do solo, 41, e0160419. https://doi.org/10.1590/18069657rbcs20160419

Scapinelli, A., Deina, F. R., Valadão Junior, D. D., Valadão, F. C. A., \& Pereira, L. B. (2016). Sistema radicular e componentes produtivos do girassol em solo compactado. Bragantia, 75(4), 474-486. https://doi.org/10.1590/1678-4499.286

Scherer-Lorenzen, M. (2008). Functional diversity affects decomposition processes in experimental grasslands. Funct. Ecol. 22(3), 547-555.

https://doi.org/10.1111/j.1365-2435.2008.01389.x

Secretaria da Agricultura e da Pesca (SEAP). Available in:

https://www.sc.gov.br/index.php/noticias/temas/agricultura-e-pesca/santa-catarina-tem-safra-r ecorde-de-cebola. 2017.

Silva, I. R., Mendonça, E. S. Matéria orgânica do solo. In: Novais, R. F., Alvarez, V. V. H., Barros, N. F., Fontes, R. L. F., Cantarutti, R. B., Neves, J. C. L. (Ed.). Fertilidade do solo. Viçosa: Sociedade Brasileira de Ciência do Solo, 2007. p. 275-374.

Soil Survey Staff. Keys to soil taxonomy (11th ed.). United States Department of Agriculture, Washington, DC: Natural Resources Conservation Service. 2010.

Souza Nunes, R. D., Lopes, C., Sousa, D. M. G. D., \& Carvalho Mendes, I. D. (2011) Sistemas de manejo e os estoques de carbono e nitrogênio em latossolo de cerrado com a sucessão soja-milho. Revista Brasileira de Ciência do Solo, 35(4), 1407-1419. https://doi.org/10.1590/S0100-06832011000400035

Tivet, F., Sá, J.C.M., Lal, R., Briedis, C., Borszowskei, P. R., Santos, J. B., ... Séguy, L. (2013). Aggregate $C$ depletion by plowing and its restoration by diverse biomass-C inputs under no-till in sub-tropical and tropical regions of Brazil. Soil and tillage research, 126, 203-218. https://doi.org/10.1016/j.still.2012.09.004

Veras, M. D. S., Ramos, M. L. G., Oliveira, D. N. S., Figueiredo, C. C. D., Carvalho, A. M. D., Pulrolnik, K., \& Souza, K. W. D. (2016). Cover crops and nitrogen fertilization effects on nitrogen soil fractions under corn cultivation in a no-tillage system. Revista Brasileira de Ciência do Solo, 40. https://doi.org/10.1590/18069657rbcs20150092

Vezzani, F. M., \& Mielniczuk, J. (2011). Aggregation and carbon stock in Argisol submitted to different agricultural management practices. $R$ Bras $C i$ Solo, 35, 213-223. https://doi.org/10.1590/S0100-06832011000100020

Wang, F., \& Weil, R. R. (2018). The Form and Vertical Distribution of Soil Nitrogen as 
Affected by Forage Radish Cover Crop and Residual Side-Dressed N fertilizer. Soil Science, 183(1), 22-33. https://doi.org/10.1097/SS.0000000000000224

Xu, S., Chen, X., \& Zhuang, J. (2019). Opposite influences of mineral-associated and dissolved organic matter on the transport of hydroxyapatite nanoparticles through soil and aggregates. Environmental Research, 171, 153-160. https://doi.org/10.1016/j.envres.2019.01.020

Zhong, X. L., Li, J. T., Li, X. J., Ye, Y. C., Liu, S. S., Hallett, P. D., \& Naveed, M. (2017). Physical protection by soil aggregates stabilizes soil organic carbon under simulated $\mathrm{N}$ deposition in a subtropical forest of China. Geoderma, 285, 323-332. https://doi.org/10.1016/j.geoderma.2016.09.026

\section{Copyright Disclaimer}

Copyright for this article is retained by the author(s), with first publication rights granted to the journal.

This is an open-access article distributed under the terms and conditions of the Creative Commons Attribution license (http://creativecommons.org/licenses/by/4.0/). 